\title{
INTERNATIONAL COMPETITION AND \\ EXCHANGE RATE SHOCKS: A \\ CROSS-COUNTRY INDUSTRY ANALYSIS \\ OF STOCK RETURNS
}

John M. Griffin

René M. Stulz

Working Paper 6243 
NBER WORKING PAPER SERIES

\title{
INTERNATIONAL COMPETITION AND \\ EXCHANGE RATE SHOCKS: A \\ CROSS-COUNTRY INDUSTRY ANALYSIS \\ OF STOCK RETURNS
}

\author{
John M. Griffin \\ René M. Stulz
}

Working Paper 6243

http://www.nber.org/papers/w6243

\author{
NATIONAL BUREAU OF ECONOMIC RESEARCH \\ 1050 Massachusetts Avenue \\ Cambridge, MA 02138 \\ October 1997
}

We thank Andrew Karolyi for helpful discussions. This paper is part of NBER's research program in Asset Pricing. Any opinions expressed are those of the authors and not those of the National Bureau of Economic Research.

(C) 1997 by John M. Griffin and René M. Stulz. All rights reserved. Short sections of text, not to exceed two paragraphs, may be quoted without explicit permission provided that full credit, including $(\mathbb{O}$ notice, is given to the source. 
International Competition and Exchange Rate

Shocks: A Cross-Country Industry Analysis of

Stock Returns

John M. Griffin and René M. Stulz

NBER Working Paper No. 6243

October 1997

Asset Pricing

ABSTRACT

It is widely accepted that, for some industries, competition across countries is economically important and that this competition is strongly affected by exchange rate changes. This paper explores the validity of this view using weekly stock return data on 320 industry pairs in six countries from 1975 to 1997 . It is found that common shocks to industries across countries are more important than competitive shocks. Weekly exchange rate shocks explain almost nothing of the relative performance of industries. Using returns measured over longer horizons, the importance of exchange rate shocks increases slightly and the importance of common shocks to industries increases more substantially. Both industry and exchange rate shocks are more important for industries that produce goods traded internationally, but the importance of these shocks is economically small for these industries as well.

John M. Griffin

Department of Finance

Arizona State University

PO Box 873906

Tempe, AZ 85287-3906
René M. Stulz

Fisher College of Business

The Ohio State University

1775 College Road

Columbus, OH 43210-1399

and NBER

stulz@cob.ohio-state.edu 


\section{Introduction.}

It is widely argued by economists, journalists and politicians around the world that some of the industries in their country compete vigorously with industries in other countries and that exchange rate shocks affect their competitiveness. For instance, in the U.S., it is routinely stated that some U.S. industries compete with Japanese industries and that an appreciation of the yen is good for these U.S. industries and bad for the competing Japanese industries. In this paper, we explore the stock price impact of competition between industries located in different countries and address the question of whether the competitive effects of bilateral exchange rate shocks are economically significant. We find that after controlling for market-wide effects the average relation between a U.S. industry and its counterpart in another country is generally economically trivial as is the effect of exchange rate shocks on the U.S. industry. The industry and exchange rate effects are larger but still surprisingly small in the other countries we consider. There is no evidence that these effects are larger in the 1990s than for the whole sample period, but the exchange rate effects are noticeably larger for Japan from 1985 to 1989 . When there is a relation between the industry in one country and the industry in another country, this relation is generally positive indicating that common industry effects dominate competitive effects.

Our investigation uses industry data for the U.S., Canada, the U.K., France, Germany and Japan from 1975 to 1997 . All our industry indices come from a common source which uses the same approach to assign firms to industries in each country. This makes it possible for us to match industries across countries. Because of the considerable attention paid to the role of the yen in the competitiveness of Japan, we use the U.S.-Japan country pair to examine our 
results in detail. After having done so, we summarize the evidence for the other country pairs and explain where it differs from the U.S.-Japan country pair.

The paper is related to two literatures that have received much attention recently. One literature investigates the relation between stock returns and foreign exchange returns. With the exception of Williamson (1997), this literature uses trade-weighted exchange rates and ignores industry effects. Williamson (1997) examines the determinants of exchange rate exposures for automotive firms that compete internationally. He shows that exchange rate exposures depend on market and firm characteristics, so that exposures can differ across firms within a country in sign and significance. He finds statistically significant competitive effects of exchange rate shocks between Japan and the U.S. in a specification that regresses the difference in industry returns between the two countries on the bilateral exchange rate. His results hold for our sample and industry classifications. However, our evidence indicates that the automotive industry is more sensitive to exchange rate shocks than the typical industry and that even for that industry the economic importance of exchange rate shocks is small. After accounting for industry and market effects, the exchange rate shocks explain about $3 \%$ of the variance of returns of the automotive assembly industry in Japan. This is a small effect, but it turns out that across more than 300 industry pairs worldwide exchange rate shocks have more explanatory power in only nine industries over our sample period. In other words, the explanatory power of exchange rate shocks for the Japanese automotive industry is higher than for almost any other industry in our sample. In contrast, the bilateral exchange rate explains nothing of the excess return of the U.S. automotive assembly industry.

The remainder of the literature on exchange rate effects generally uses trade-weighted exchange rates and does not control for industry effects. Much of this literature focuses on 
U.S. firms and finds weak contemporaneous relationships between exchange rates and stock returns. Jorion (1990) shows that these exposures are greater for multinational firms. The problem with focusing on U.S. firms is that international trade is not as important for the U.S. as it is for other, smaller countries, so exchange rate effects might be small for U.S. firms for that reason. For instance, $\mathrm{He}$ and $\mathrm{Ng}$ (1997) find more significant exchange rate exposures in Japan using conventional regressions where they regress firm returns on the national market and a trade-weighted exchange rate return. In our empirical evidence, the U.S. is quite different from other countries in that the excess returns of U.S. industries depend much less on the foreign industry returns and on the exchange rate returns. This is consistent with international trade being less important for U.S. firms at the industry level than in other countries. Bodnar and Gentry (1993) find that the distinction between industries that produce traded goods and industries that produce non-traded goods is important across U.S., Canadian and Japanese industries using equally-weighted portfolios of firms within industries. Equallyweighted portfolios produce information about average exchange rate exposure in an industry. They do not tell us about the economic significance of exchange rate shocks for an industry as a whole since an industry might be dominated by one or several large firms whose exposures have little impact on an average computed across a large number of firms.

Surprisingly, Bartov and Bodnar (1994) find that lagged exchange rate returns have more explanatory power for the returns of U.S. firms than contemporaneous exchange rate returns. $\mathrm{He}$ and $\mathrm{Ng}$ (1997) do not find this result for Japan, however. In recent work, Allayannis (1996a, 1996b) shows that the relation changes through time and is stronger when the returns measurement interval is longer. We find that it is generally the case across all countries in our sample that the explanatory power of exchange rates increases as the 
measurement interval increases. However, this effect is extremely small. In regressions of industry returns on exchange rate returns, this effect means that the adjusted $R^{2}$ moves from an average of less than $0.5 \%$ to close to an average of $1.5 \%$ when one uses yearly returns instead of weekly returns. The absolute slope coefficient for the exchange rate return in regressions of industry returns on exchange rate returns increases substantially as the measurement interval increases, but only for traded goods industries. For these industries, the average coefficient decreases from -0.03 to -0.13 as the time-interval increases from weekly to yearly.

The other related literature is the one that focuses on the importance of country, industry and currency factors in stock returns. ${ }^{1}$ This literature often estimates the fraction of stock return variance that can be explained by one of these three factors. This literature generally finds that country effects are large and industry effects are small. However, the results in this literature seem sensitive to the countries included in the study, to the definition of industries, and to the sample period. This literature does not focus on country pairs like we do. With country pairs, competitive shocks imply that one country's industry is made better off at the expense of the other country's industry. We find almost no industry where this is the case. If exchange rate shocks have competitive effects, these effects can obscure cross-country industry comovements because competitive exchange rate shocks have effects of opposite sign on industries in different countries. Allowing for such effects does not change our assessment of the importance of competitive effects, however. We find that industry effects vary widely across industries and countries. Traded goods industries are substantially more likely to have significant industry effects and industry effects are more important for Canada and the UK than they are for other countries. Though the literature emphasizes that the effect of exchange rate 
shocks increases when the measurement interval increases, this effect is dwarfed by the increased importance of industry effects for traded goods industries as one moves from a weekly to a yearly measurement interval. Using yearly returns, exchange rate returns explain $1.5 \%$ of the variation in industry returns in excess of the market whereas industry effects explain an:additional $3.8 \%$.

The paper proceeds as follows. In section 2 , we describe the industry classifications and characterize the market returns and exchange rates used in the analysis. In section 3 , we examine the impact of exchange rates and U.S. industry returns on Japanese excess industry returns. Section 4 explores whether allowing for interactions between exchange rate shocks and industry shocks uncovers competitive effects that we failed to discover in section 3 . In Section 5, we extend our analysis to the UK, Germany, France, Canada, and the U.S. and the time-period is lengthened to monthly, quarterly, and yearly intervals. Section 6 provides a brief conclusion.

\section{Data Description and Preliminary Statistics}

Weekly returns for the industries, market returns, and exchange rates are obtained from Datastream International from January 8, 1975 to June 23, 1997. The advantage of this data source is that Datastream applies the same criteria for defining industries across countries. Consequently, this minimizes the risk of finding low cross-country industry comovements because of misclassification of firms. Datastream classifies indices into one of six levels. Level 1 is the market index for a country and levels 2 and 3 are general industry grouping. At each additional level there are more disaggregated industry definitions until the most disaggregated

\footnotetext{
${ }^{1}$ This literature has been marked by controversy on the relative importance of industry and country factors. See
} 
industry classification, level 6. Griffin and Karolyi (1997) argue that using broad industrial classifications leads to lumping of industries, often of little similarity, and that the most disaggregated industry indices should be used to examine industry effects. Following their recommendation, we only report results for level 6 industries.

Throughout the study, we use industry indices that are common to country pairs. For instance, for the U.S. there are 72 level 6 industries and in Japan there are 59. However, since we focus on cross-country industry relationships, when examining Japanese industry returns we only examine the 56 industries which are common to the U.S. and Japan. Table I displays the number of level 6 industries for which data is available in each of the six countries used in the analysis.

Examining the nature of the industries reveals a number of industries which produce a good that is traded internationally, but also many with no underlying internationally traded commodity price. We call the former industries 'traded' industries and the later 'non-traded' industries. Bodnar and Gentry (1993) examine equally-weighted industry portfolios and find that Canadian and Japanese non-traded goods industries gain relative to traded goods industries with an appreciation of the domestic currency. Griffin and Karolyi (1997) find that traded goods industries exhibit higher industry effects. Dividing our sample into traded and non-traded goods industries yields 21 traded and 51 non-traded industries that have coverage in the U.S. The 21 traded goods industries are auto assemblers, three chemical industries, computer software, electrical equipment, electronic equipment, footwear and leather, gold mining, metallurgy, three oil industries, other mining, paper and packaging, pharmaceuticals, steel, textiles/other, tobacco, vehicle components and vehicle distribution. Admittedly, such 
classifications are subjective since many industries have a small traded goods component, but experimenting with alternate assignments of firms to traded and non-traded goods industries did not impact our findings.

The numbers of traded and non-traded goods industries in each country in our sample with availability in the US are displayed in Table I. Of the 320 industry indices that have coverage in 1985, 208 are non-traded goods industries, while 93 are traded industries. Even though there are over twice as many non-traded goods industries, the combined market value of the traded goods industries is 63.7 percent of the total dollar denominated market value in January $1985 .^{2}$

Throughout our analysis, we use industry returns net of country returns. There are two reasons for this. The first reason can be explained using the Japan and U.S. pair as an example. Over our sample period, the Japanese market index in yen and the U.S. market index in dollars have a correlation of 0.24 . When considering the returns of an industry in the U.S. and the same industry in Japan, one would therefore expect these two industries to have a similar correlation as that between the indices. This correlation does not reflect industry factors but rather the effect of business cycles and other aggregate macroeconomic variables. ${ }^{3}$ The second reason is that the stock market and exchange rates might be correlated because both are related to similar macroeconomic variables. Using industry returns without controlling for market movements, it might seem that exchange rate effects are important when in fact these

\footnotetext{
${ }^{2}$ The ratio of the total value of traded goods industries to the total value of non-traded goods industries does not materially change from the beginning to end of the sample period.

${ }^{3}$ Cross-country stock index return correlations have been studied extensively. See King, Sentana, Wadhwani (1994), Longin and Solnik (1995) and DeSantis and Gerard (1997) for recent evidence that correlations change over time.
} 


\section{Table I. Number and dollar market value of traded and non-traded goods industries for each country.}

To be included in the analysis the Datastream value-weighted, level 6 industries returns must be available for a minimum of two years. Industrial indices that have no representation in the US are excluded from the analysis. The number of industries prior to the U.S. availability restriction is included in parentheses. The dollar market values (MV) are in millions and taken as of January $7,1985$.

\begin{tabular}{lcccccc}
\hline \multicolumn{1}{r}{ Country } & \multicolumn{2}{c}{ Non-Traded Ind. } & \multicolumn{2}{c}{ Traded Ind. } & \multicolumn{2}{c}{ All Industries } \\
& Number & MV & Number & MV & Number & MV \\
\hline United States & 51 & 13,254 & 21 & 24,234 & 72 & 37,488 \\
Japan & $40(43)$ & 7889 & 16 & 14,700 & 56 & 22,589 \\
United King. & $42(46)$ & 2545 & 17 & 3435 & 59 & 5980 \\
Germany & $20(21)$ & 1727 & 11 & 2929 & 31 & 4656 \\
France & $24(26)$ & 577 & 12 & $\mathbf{8 5 5}$ & 36 & 1432 \\
Canada & $31(33)$ & 1409 & 16 & $\mathbf{2 0 6 3}$ & 47 & 3472 \\
\hline Total & $\mathbf{2 0 8}$ & $\mathbf{2 7 , 4 0 1}$ & $\mathbf{9 3}$ & $\mathbf{4 8 , 2 1 6}$ & $\mathbf{3 0 1}$ & $\mathbf{7 5 , 6 1 7}$ \\
\hline
\end{tabular}


inferences could solely be due to correlations between macroeconomic factors and exchange rates. If exchange rate effects are important for some industries, they should affect the performance of these industries after abstracting from business cycle effects at the level of the country.

To purge a country's industry return from the return on the market in that country, we could proceed in several different ways. In particular, we could estimate a regression of the industry return on the market return and focus on the residual from that regression in our tests. Alternatively, we could simply subtract the market return from the industry return. We used both approaches. However, in the following we only report results where we subtract the market return from the industry return, which has the interpretation of the excess return of the industry over the market. The method we use to eliminate the market effect has no impact on our conclusions. However, the excess return has the advantage that it can be obtained by a portfolio strategy of going long the industry and short the market. Further, it corresponds to the return of a portfolio that has no currency risk in the limit of continuous-time and hence has no currency dimension.

Table II displays means, standard deviations, and correlations for the market indices and exchange rates for the entire January 8, 1975 to June 23, 1997 period as well as subperiods. The correlations between the indices change across subperiods. Generally, the correlations are lowest in the 1975 to 1979 subperiod and highest in the 1980 to 1984 period. For our exchange rate measure we use the change in the dollar/currency exchange rate as described in the data appendix. Table II shows that the yen appreciates in all our subperiods except for the one from 1980 to 1984 . For the whole period, the Japanese stock market is 


\section{Table II. Summary Statistics for Explanatory Variables}

Means, standard deviations, and correlations are presented for U.S., Japanese (JP), UK, German $(B D)$, Canadian $(C N)$, and French $(F R)$ value-weighted Datastream local currency market index weekly returns and the log change in the weekly U.S. dollar per currency nominal exchange rate. Both market returns and currency changes are denoted in percent per week. Full sample and subsample results are displayed.

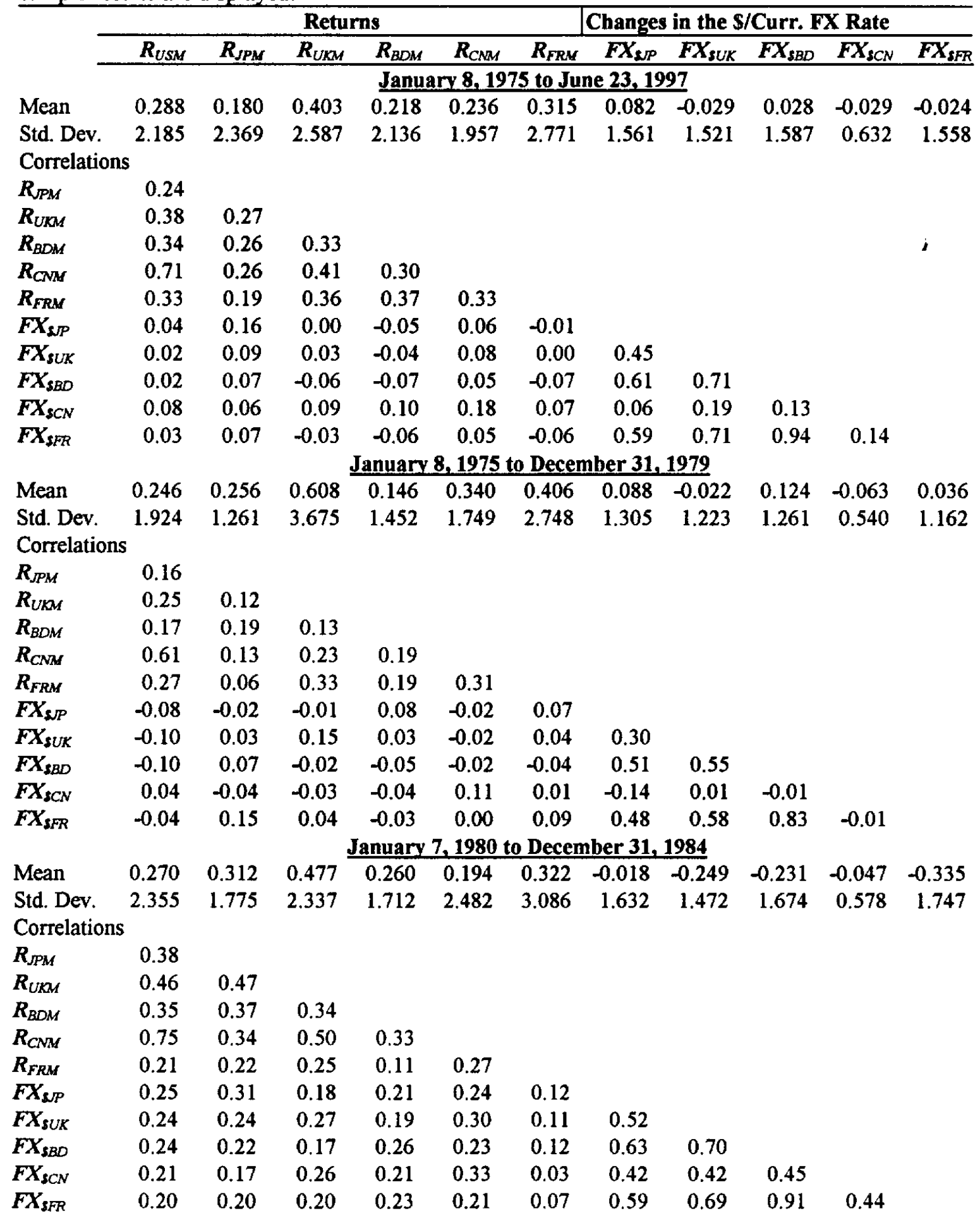




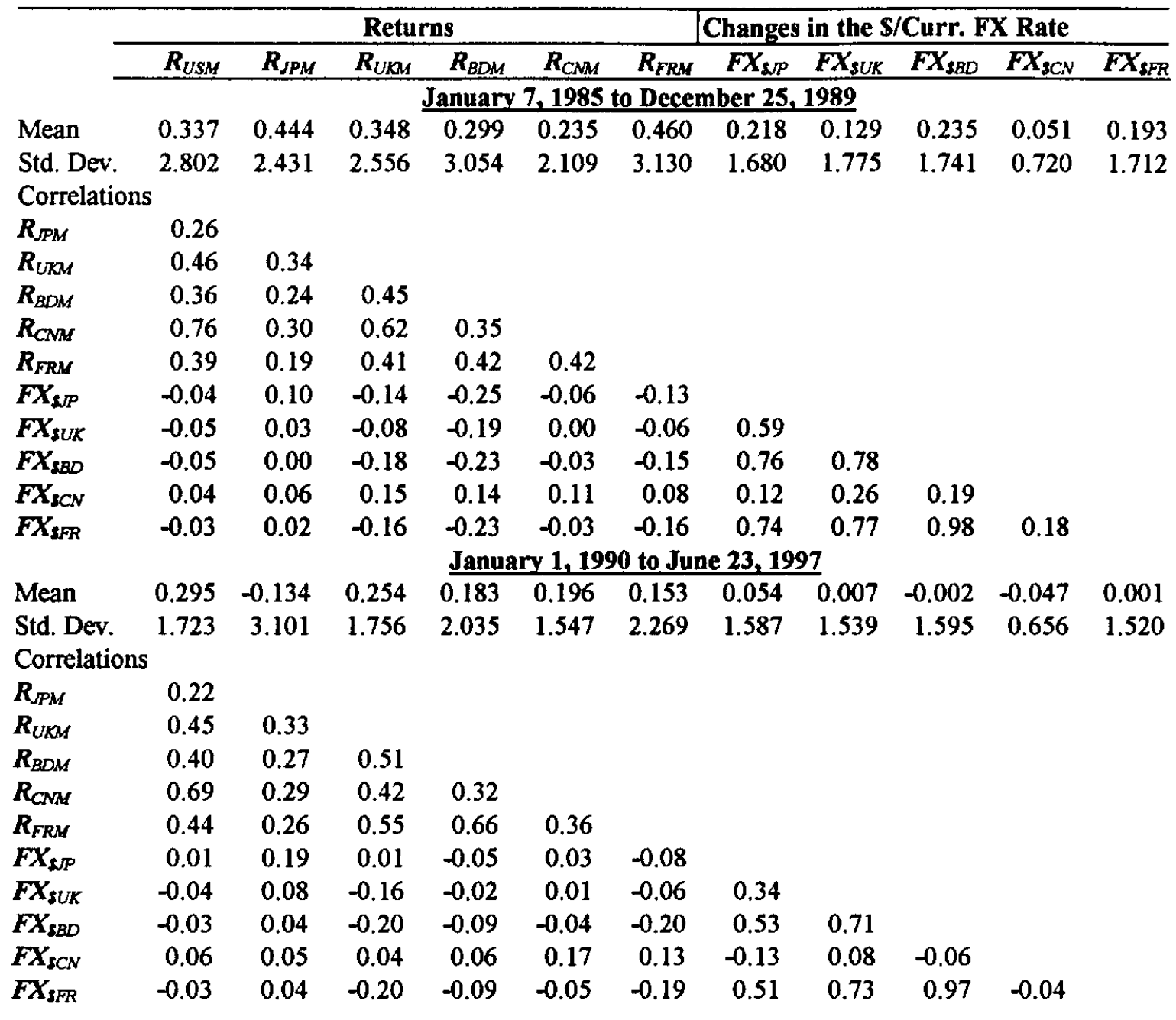


positively correlated with the dollar/yen exchange rate. This means that an appreciation of the yen is associated with a decrease in the Japanese stock market. This is also the case for subperiods, except for the first. The fact that an increase in the dollar price of the yen affects the Japanese stock market positively suggests that the same increase should affect the U.S. stock market adversely if exchange rate shocks have a competitive effect. This is only partly true, however. For the whole sample period, the U.S. market has a weak positive correlation with the dollar/yen exchange rate, but the correlation is negative from 1975 to 1979 and from 1985 to 1989 .

\section{Competitive effects between the U.S. and Japan evaluated using weekly returns.}

Table III provides estimates of two sets of regressions for the whole sample and various subsamples. In the first set of regressions the Japanese industry excess return is regressed on the exchange rate return. The regressions provide estimates of the importance of exchange rate effects on the industry excess returns. We then provide estimates of a second set of regressions which adds the excess return of the U.S. industry as an explanatory variable. The distributions of the regression coefficients for those regressions, their t-statistics, and the adjusted $R^{2}$ 's for the whole sample period are shown in Figure 1 as well as summarized in the table. If the exchange rate shocks have economically important competitive effects on an industry, we expect a negative coefficient on the exchange rate which implies that a change in the exchange rate affects the industry significantly and we expect exchange rate shocks to explain a significant fraction of the variance of the industry returns. For the regressions with the U.S. industry returns, economically dominant competitive effects would imply a negative 


\section{Table III. Japanese Industry Excess Weekly Returns Regressed on the Exchange rate and the U.S. Industry Excess Returns.}

Panel A presents coefficient estimates, $t$-statistics (in parentheses), and adjusted $R^{2}$ from regressions for the Japanese yen denominated weekly market return regressed on the dollar/yen exchange rate and separately for both the exchange rate and the U.S. dollar denominated market return for the period from January 8, 1975 to June 23,1997 . These estimates are also displayed for seventeen traded industry indices in excess of the value-weighted Japanese market index $\left(r_{J A i}=R_{J A i}-R_{J A M}\right)$ regressed separately on the exchange rate and the corresponding U.S. dollar denominated return index return in excess of the U.S. market return $\left(r_{U S i}=R_{U S i}-R_{U S M}\right)$. Average coefficients, $t$-statistics, and adjusted $R^{2}$ are provided for the seventeen traded and 41 non-traded Datastream level 6 disaggregate industries that exist both in Japan and the US. The number of coefficients that are significantly positive at the upper and lower five percent level for traded and non-traded industries is also presented. Panel B provides these summary statistics for four sub-periods beginning in 1975. The OLS regressions for the regressions with the exchange rate and the industry returns in excess of their respective market return are as follows.

\begin{tabular}{|c|c|c|c|c|c|c|c|c|c|}
\hline \multirow{3}{*}{ Panel A } & & & & & & & & & \\
\hline & & & & & & & & & \\
\hline & $a$ & $\boldsymbol{b}$ & $d$ & adj. $R^{2}$ & & $a$ & $\boldsymbol{b}$ & $d$ & $\operatorname{adj} . R^{2}$ \\
\hline \multirow[t]{4}{*}{ Market Index } & 0.00 & 0.24 & & & Oil Explo. \& Prod. & 0.00 & -0.04 & & \\
\hline & (2.35) & $(5.44)$ & & 0.024 & & $-(0.47)$ & $-(0.39)$ & & -0.001 \\
\hline & 0.00 & 0.23 & 0.25 & & & 0.00 & -0.03 & 0.30 & \\
\hline & $(1.33)$ & $(5.29)$ & $(8.25)$ & 0.077 & & $-(0.25)$ & $-(0.33)$ & $(4.82)$ & 0.018 \\
\hline \multirow[t]{4}{*}{ Auto Assemblers } & 0.00 & -0.25 & & & Oil Integrated & 0.00 & 0.18 & & \\
\hline & $(0.88)$ & $-(5.41)$ & & 0.024 & & $-(0.13)$ & $(2.89)$ & & 0.006 \\
\hline & 0.00 & -0.25 & 0.05 & & & 0.00 & 0.19 & 0.21 & \\
\hline & $(0.92)$ & $-(5.43)$ & $(1.77)$ & 0.025 & & $-(0.16)$ & $(3.06)$ & $(4.38)$ & 0.022 \\
\hline \multirow[t]{4}{*}{ Chems Commodity } & 0.00 & -0.08 & & & Other Mining & 0.00 & -0.11 & & \\
\hline & $-(0.45)$ & $-(2.56)$ & & 0.005 & & $-(0.14)$ & $-(1.44)$ & & 0.001 \\
\hline & 0.00 & -0.08 & 0.01 & & & 0.00 & -0.11 & 0.10 & \\
\hline & $-(0.45)$ & $-(2.55)$ & $(0.41)$ & 0.004 & & $(0.00)$ & $-(1.51)$ & $(2.44)$ & 0.005 \\
\hline \multirow[t]{4}{*}{ Chems Specialty } & 0.00 & -0.13 & & & Paper \& Packaging & 0.00 & -0.06 & & \\
\hline & $-(0.33)$ & $-(3.10)$ & & 0.007 & & $-(0.43)$ & $-(1.59)$ & & 0.001 \\
\hline & 0.00 & -0.12 & -0.05 & & & 0.00 & -0.06 & 0.03 & \\
\hline & $-(0.34)$ & $-(3.06)$ & $-(1.50)$ & 0.008 & & $-(0.41)$ & $-(1.62)$ & $(0.83)$ & 0.001 \\
\hline \multirow[t]{4}{*}{ Chems Mats Tech } & 0.00 & -0.12 & & & Pharmaceutical & 0.00 & -0.10 & & \\
\hline & $(0.21)$ & $-(3.35)$ & & 0.009 & & $(1.09)$ & $-(2.37)$ & & 0.004 \\
\hline & 0.00 & -0.12 & -0.01 & & & 0.00 & -0.10 & 0.00 & \\
\hline & $(0.20)$ & $-(3.35)$ & $-(0.37)$ & 0.008 & & $(1.09)$ & $-(2.37)$ & $-(0.03)$ & 0.003 \\
\hline \multirow[t]{4}{*}{ Computer Software } & 0.00 & -0.21 & & & Steel & 0.00 & 0.13 & & \\
\hline & $-(0.60)$ & $-(1.99)$ & & 0.004 & & $-(0.91)$ & (3.13) & & 0.008 \\
\hline & 0.00 & -0.21 & 0.03 & & & 0.00 & 0.13 & 0.03 & \\
\hline & $-(0.64)$ & $-(2.00)$ & $(0.44)$ & 0.003 & & $-(0.83)$ & $(3.13)$ & $(1.31)$ & 0.008 \\
\hline \multirow[t]{4}{*}{ Electrical Equip. } & 0.00 & -0.19 & & & Textiles Other & 0.00 & -0.01 & & \\
\hline & $(0.90)$ & $-(5.17)$ & & 0.022 & & $-(0.37)$ & $-(0.23)$ & & -0.001 \\
\hline & 0.00 & -0.19 & 0.06 & & & 0.00 & -0.01 & 0.01 & \\
\hline & $(0.85)$ & $-(5.19)$ & $(1.52)$ & 0.023 & & $-(0.40)$ & $-(0.21)$ & $(1.01)$ & -0.001 \\
\hline \multirow[t]{4}{*}{ Electronic Equip. } & 0.00 & -0.33 & & & Vehicle Component & 0.00 & -0.21 & & \\
\hline & $(0.78)$ & $-(6.72)$ & & 0.036 & & $(0.67)$ & $-(5.73)$ & & 0.027 \\
\hline & 0.00 & -0.33 & 0.14 & & & 0.00 & -0.21 & 0.11 & \\
\hline & $(0.85)$ & $-(6.83)$ & $(3.49)$ & 0.045 & & $(0.64)$ & $-(5.82)$ & (3.42) & 0.035 \\
\hline
\end{tabular}




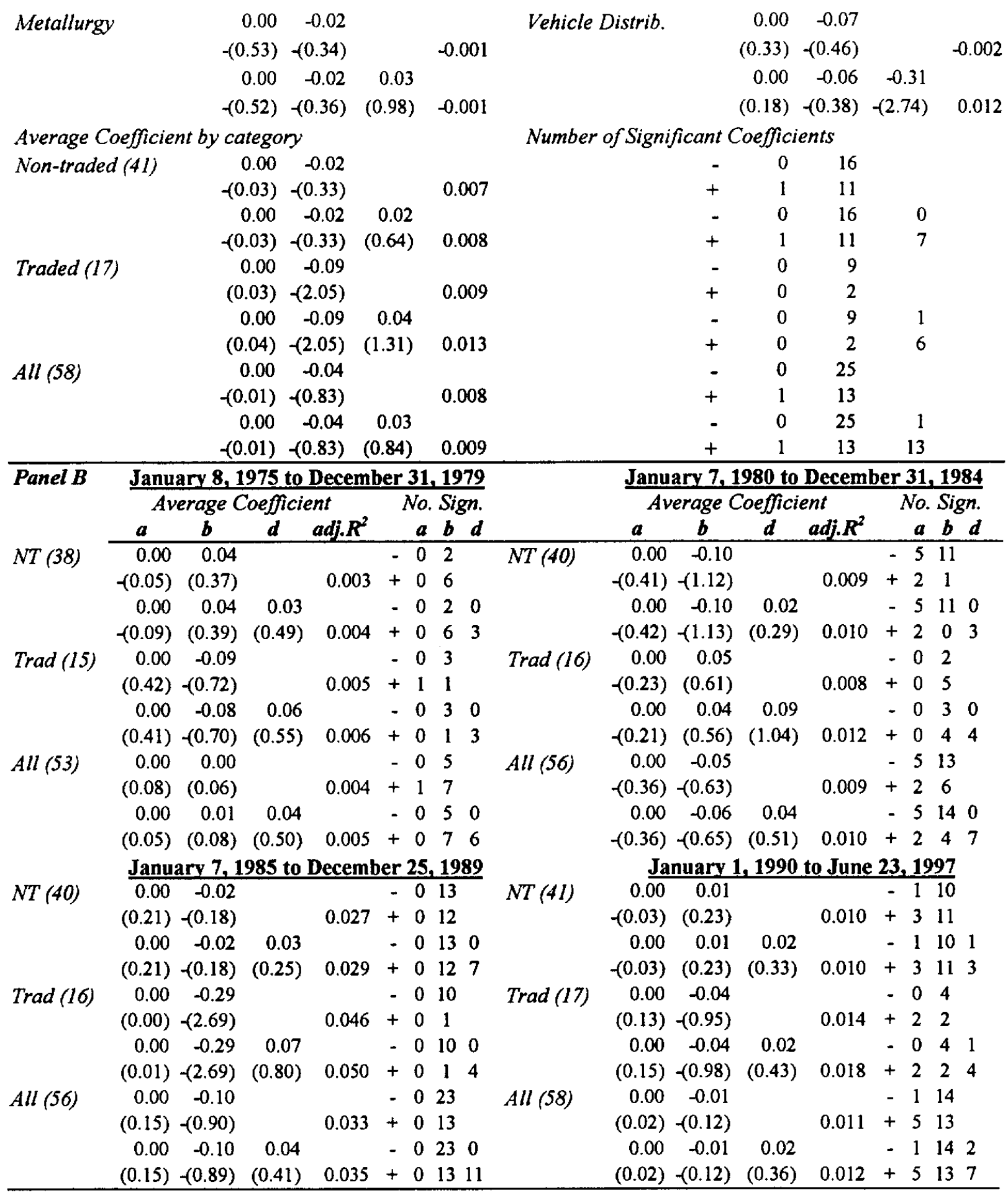


effect of shocks to the U.S. industry on the return of the Japanese industry, so that on average what is good for the Japanese industry would be bad for the U.S. industry. In contrast, common effects are dominant if the coefficient on the U.S. industry returns is significantly positive. In this case, what is good for the U.S. industry is good on average for the Japanese industry also.

In panel A, we report the Ordinary Least Squares (OLS) regression estimates for each of the traded goods industries over our whole sample period. All of the industries except for integrated oil and steel have a negative and largely significant exchange rate coefficient. This is consistent with exporting industries losing from an appreciation in the currency and importing industries (oil and steel) gaining from a currency appreciation. At the same time, however, the economic significance of the exchange rate effect is limited. The average coefficient is -0.09 , which means that a $1 \%$ appreciation of the yen decreases the value of a traded goods industry by $0.09 \%$ on average. Further, the adjusted $R^{2}$ coefficient is $0.9 \%$, which means that exchange rate shocks on average explain less than $1 \%$ of the variance of the returns of a traded goods industry. The auto assembly and vehicle component industries have the highest absolute value slope coefficients and highest adjusted $R^{2}$ 's among traded goods industries except for the electronic equipment industry. Only four Japanese industries out of the fifty-eight traded goods and nontraded industries have a higher exchange rate slope coefficient than the Japanese automotive assembly industry, indicating that the automotive industry indeed has an extreme sensitivity to foreign exchange. However, an extreme sensitivity does not mean an economically large sensitivity since a $1 \%$ appreciation of the yen implies a negative return of $0.25 \%$.

When we add the U.S. industry excess return to the regression, auto assemblers, electronic equipment, both oil industries, other mining, and vehicle component and distribution have positive and significant coefficients on the U.S. excess industry return. This implies that competitive 
effects are dominated by common cross-country industry effects. For non-traded (traded) goods industries, a one percent excess return for the U.S. industry implies a $0.02 \%(0.04 \%)$ excess return for the Japanese industry. None of the non-traded goods industries have an industry coefficient that exceeds 0.1 in absolute value. Four traded goods industries have such coefficients: the two oil industries and two vehicle industries. The inclusion of industry excess returns, however, has little effect on either the coefficient or the $t$-statistic of the exchange rate coefficient. Further, adding the industry excess return to the regression has almost no impact on the adjusted $R^{2}$ in non-traded goods industries and some impact in traded goods industries. The adjusted $R^{2}$ for non-traded (traded) goods industries is $0.7 \%(0.9 \%)$ on average for the regressions with just the exchange rate, and $0.8 \%(1.3 \%)$ for regressions with the U.S. industry excess return included as well. For these regressions, Figure 1 shows that most adjusted $R^{2} \mathrm{~s}$ are extremely small. Also of interest in Figure 1 is that the range of coefficient values is between -0.33 and 0.34 . This indicates that while exchange rate exposure varies across industries, the economic magnitude of this exposure is relatively small for most industries.

We do not report individually the estimates for the non-traded goods industries. For the 17 traded goods industries, the exchange rate coefficient is significantly negative for 9 industries and significantly positive for 2 industries. In contrast, for the 41 non-traded goods industries, the positive and negative coefficients are more balanced. The exchange rate coefficient is significantly negative for 16 and significantly positive for the other 11 industries. As a result, the average coefficient is close to zero, so that on average a one percent appreciation of the Yen decreases the value of the non-traded good industries by $0.02 \%$. The highest foreign exchange slope coefficient among all non-traded goods industries as well as all industries in absolute value is the 0.34 
Figure 1. Distribution of the summary statistics for regressions of Japanese industry excess weekly returns regressed on the yen/dollar exchange rate and the U.S. industry excess return. Plots for the coefficient estimates, the t-statistics, and the adjusted $R^{2}$ are shown below for traded and non-traded goods industries for the period January 8, 1975 to May 23, 1997.

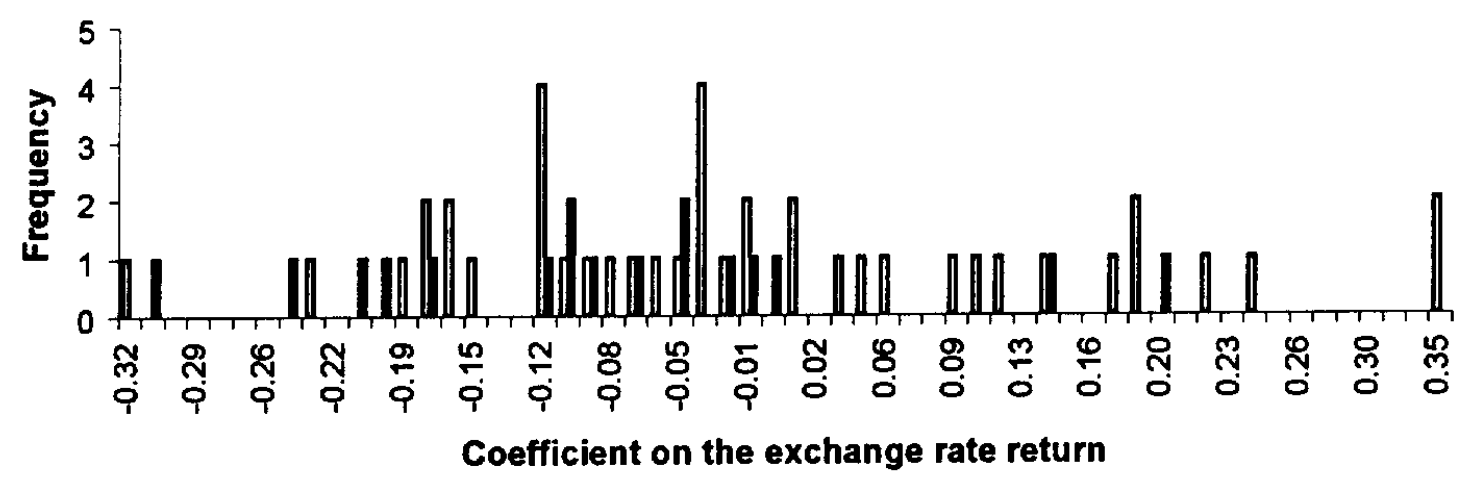

$\square$ Non-Traded $\square_{\text {Traded }}$

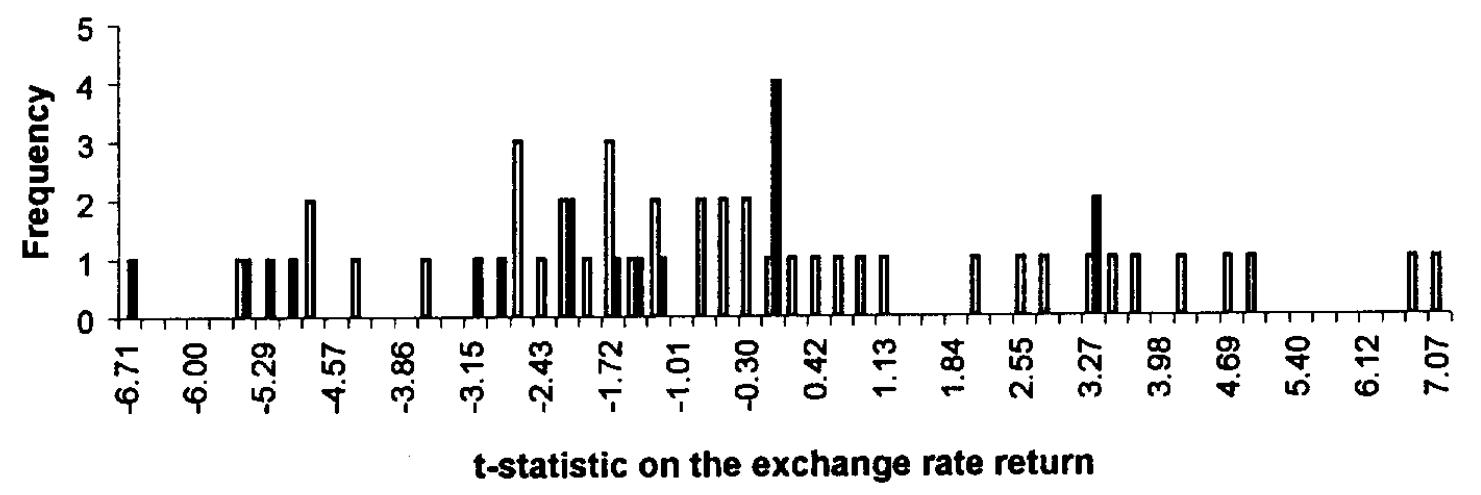

$\square_{\text {Non-Traded }} \mathbf{m}$ Traded 


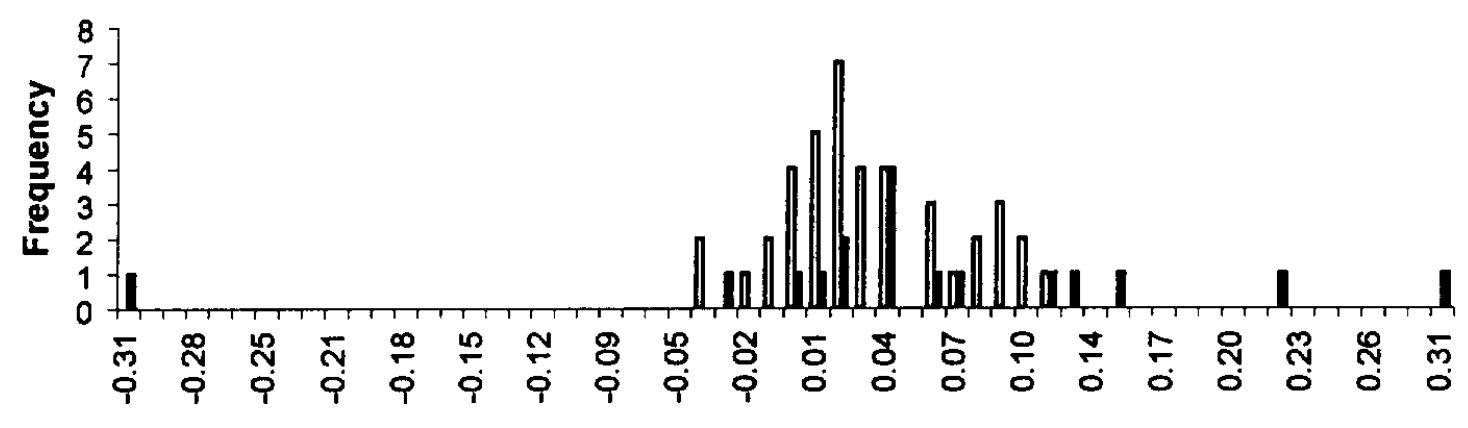
Coefficient on the US excess industry return

\section{$\square_{\text {Non-Traded }}$ Traded}

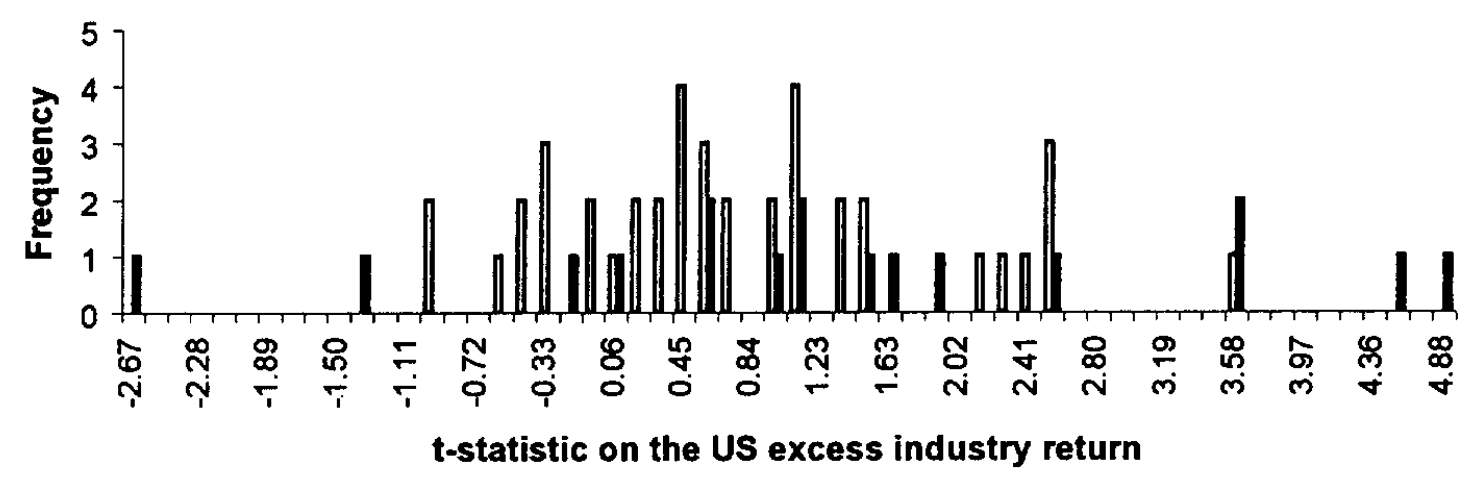

\section{$\square_{\text {Non-Traded }} \mathbf{T}_{\text {Traded }}$}

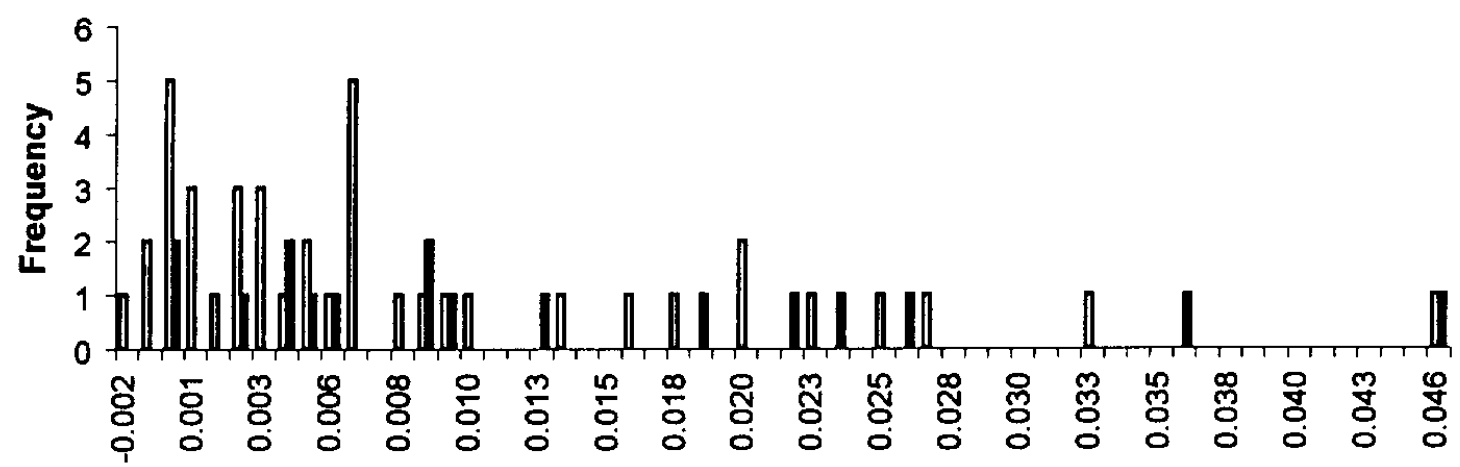

Adjusted R-squared

$\square$ Non-Traded $\mathbf{T r a d e d}$ 
positive coefficient for the electricity industry. That industry also has the largest adjusted $R^{2}$ which is $4.4 \%$. The average adjusted $R^{2}$ from the exchange rate return regressions is $0.7 \%$ and including the U.S. excess industry return only increases the $R^{2}$ to $0.9 \%$, indicating that there are almost no cross-country industry effects in non-traded goods industries.

We also provide summary statistics for four sub-periods. The subperiods are chosen so that the period of appreciation of the dollar in the 1980 s would correspond to a subperiod. This leads us to choose three subperiods of five years and then use the 1990 s as one subperiod. The only subperiod that stands out is the subperiod from January 7, 1985 to December 25, 1989. In this subperiod, the traded goods industry has much larger slope coefficients on the exchange rate. The average coefficient is -0.29 for both sets of regressions and the average t-statistic is -2.69 . Removing the month of the October 1987 crash does not materially change the coefficient estimates. Also, the adjusted $R^{2}$ is substantially higher for both traded and non-traded goods industries. At the same time, however, for the subperiod in which the exchange rate effects are the largest, they are still of limited importance, particularly in non-traded goods industries. A one percent exchange rate shock in that subperiod has an average effect of a negative excess return of $0.10 \%$. The last subperiod does not stand out. The average adjusted $R^{2}$ is $1.1 \%$ in regressions with only the exchange rate. The adjusted $R^{2} s$ are much lower than those in the third subperiod and only slightly above those in the 1980 to 1985 sub-period. Thus, it seems that if exchange rate effects have increased through time the increase is limited to the early years of the sample. For industry effects, the last subperiod is the one with the lowest industry average slope in absolute value and the only one where the average slope is the same for traded and non-traded goods industries. There is no evidence of an increase in industry effects. 
Looking in more detail at the subperiod from 1985 to 1989 , it is unusual in that it has 11 exchange rate slope coefficients in excess of 0.5 in absolute value in the exchange rate regressions. In all the other subperiods, there is no slope coefficient in excess of 0.5 in absolute value. Further, in that subperiod, there are 12 industries with an adjusted $R^{2}$ in excess of $5 \%$. The automotive assembly industry has a coefficient of -0.63 with an adjusted $R^{2}$ of $10.10 \%$ for 1985 1989 , showing again that this subperiod is unusual. The adjusted $R^{2} s$ are lower in the 1990s than in the subperiod from 1985 to 1989 , the slope coefficient on the automotive industry is -0.34 with an adjusted $R^{2}$ of $8.1 \%$. Throughout our subperiods, the industry with the highest slope coefficient in absolute value and the highest $R^{2}$ is the electronic equipment industry in the 1985 to 1989 period with a coefficient of -0.95 and an adjusted $R^{2}$ of $16.8 \%$. The fact that the subperiod from 1985 to 1989 is unusual should be helpful in exploring further the determinants of exchange rate effects. It is the subperiod with the largest yen appreciation. When we look at other countries, it will therefore be useful to look at whether high appreciation is accompanied by larger slope coefficients in absolute value and larger adjusted $R^{2}$ s.

A potential concern with our current analysis is that using OLS ignores the possibility of autocorrelation that may bias the standard errors. Testing for autocorrelation in the residuals reveals largely insignificant values and correcting for autocorrelation leads to results that do not differ materially from OLS. ${ }^{4}$ The second potential concern is that since OLS ignores crosssectional dependencies between industries, our estimates may not be efficient. Because we estimate regressions for returns in excess of the market indices, one might think that this has the

\footnotetext{
${ }^{4}$ We examine the Durbin-Watson statistic and find only three cases (out of 58) of apparent significant autocorrelation. Nevertheless, for the full set of 58 Japanese industries we perform the Praise-Winston adjustment for autocorrelation and obtain estimates that are quite similar to the OLS results reported in the paper. Even for the three industries that exhibited significant autocorrelation the adjustment does not change the significance of any of the coefficient estimates.
} 
effect of purging the major source of common variation. ${ }^{5}$ To use the seemingly-unrelated regressions estimation method (SUR) the time-series must be substantially larger than the crosssection, which is not the case for quarterly and yearly returns. Since we wish to examine the sensitivity of our results when the sample size is decreased to the quarterly and yearly interval, we report OLS estimates. Additionally, using SUR requires that we examine only those industries that have data over the entire period, however, approximately 21 percent of the Japanese industries are available for only part of the sample period.

\section{Exchange rate shocks and cross-country comovements: A more detailed look.}

The analysis in section 3 does not allow for interactions between exchange rate shocks and industry shocks. A case can be made that ignoring such interactions might obscure both industry and exchange rate effects. ${ }^{6}$ Consider an unexpected appreciation of the dollar. The competitive view of exchange rate shocks predicts that an unexpected appreciation of the dollar affects adversely the U.S. industry and positively the Japanese industry. This prediction implies that periods of volatile exchange rates are periods where shocks affect the two industries in opposite directions. One would therefore observe a negative relation between cross-country comovement and exchange rate volatility. Another concern is that exchange rate shocks might have an asymmetric effect, which would render our regressions misspecified.

To address concerns that our regressions might be misspecified, obscuring the importance

\footnotetext{
${ }^{5}$ To investigate this we re-estimate our Japanese results using seemingly unrelated regressions (SUR). Using only those industries with data available for the whole period, the SUR estimates for the exchange rate coefficients are nearly identical to those obtained from OLS. However, the coefficient and t-statistic for the US excess industry returns is generally lower than those obtained from OLS. This strengthens the evidence that the magnitude of these effects is small. These results and those controlling for autocorrelation are available upon request.

${ }^{6}$ For a discussion of how volatility affects cross-country correlations in the presence of competitive shocks, see Karolyi and Stulz (1997).
} 
of exchange rate and country effects, we include additional explanatory variables that allow for asymmetries in exchange rate shocks and allow shocks to decrease the slope coefficient on the U.S. industry. The regressions we estimate first are as follows:

$$
r_{J A i}=a_{i}+b_{i} R_{F X}+c_{i}\left|R_{F X}\right|+d_{i} r_{U S i}+e_{i}\left[R_{F X} * r_{U S i}\right]+f_{i}\left[\left|R_{F X}\right| * r_{U S i}\right]+\eta_{i} \quad \text { for } i=1, \ldots 62
$$

We first allow the exchange rate shock to affect the Japanese industry excess return for a given U.S. industry excess return. $b_{i}$ measures the exposure of the excess return to the exchange rate and should be negative if the exchange rate has competitive effects. $c_{i}$ allows for an effect of the absolute value of the exchange rate change. If the direction of the exchange rate does not matter, one expects $c_{i}=0$. We then allow for the exchange rate shock to affect the comovement between the Japanese and the U.S. industry. If competitive effects matter, one expects a U.S. industry shock to be less informative about Japanese returns if it is accompanied by a large exchange rate shock. Again, we allow for a level effect and an absolute value effect. If the competitive effect of exchange rate shocks decreases cross-country positive industry effects, one would expect a negative coefficient for $\mathrm{e}_{\mathrm{i}}$. If exchange rate shocks have competitive effects, these effects should be more important when exchange rate volatility is high and therefore industry comovements should be smaller during such periods. We therefore expect the coefficient $f_{i}$ to be negative.

Table IV presents the regression estimates. The format of the table is the same as for Table III. In Panel A, we present results for the market index and the seventeen traded goods industries and in panel B we present summary statistics for subperiods. Comparing panel B of Table III with Table IV, we find that taking into account nonlinear exchange rate effects has almost no impact on the adjusted $R^{2} s$ of the regressions. One would expect the slope coefficient on the U.S. industry to increase after taking into account exchange rate shocks. However, the average slope is slightly smaller. Surprisingly, nonlinear effects are more noticeable for non- 


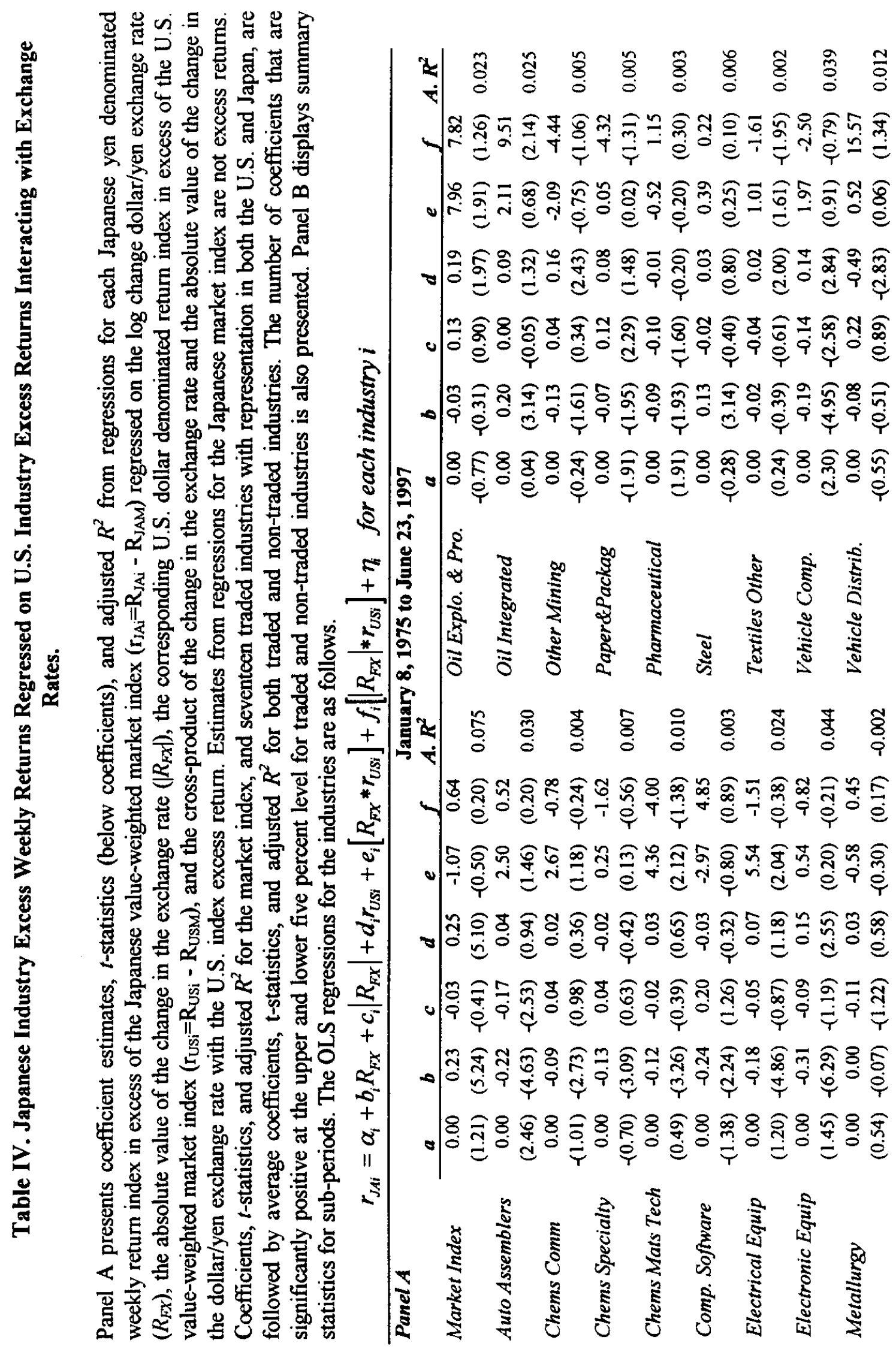




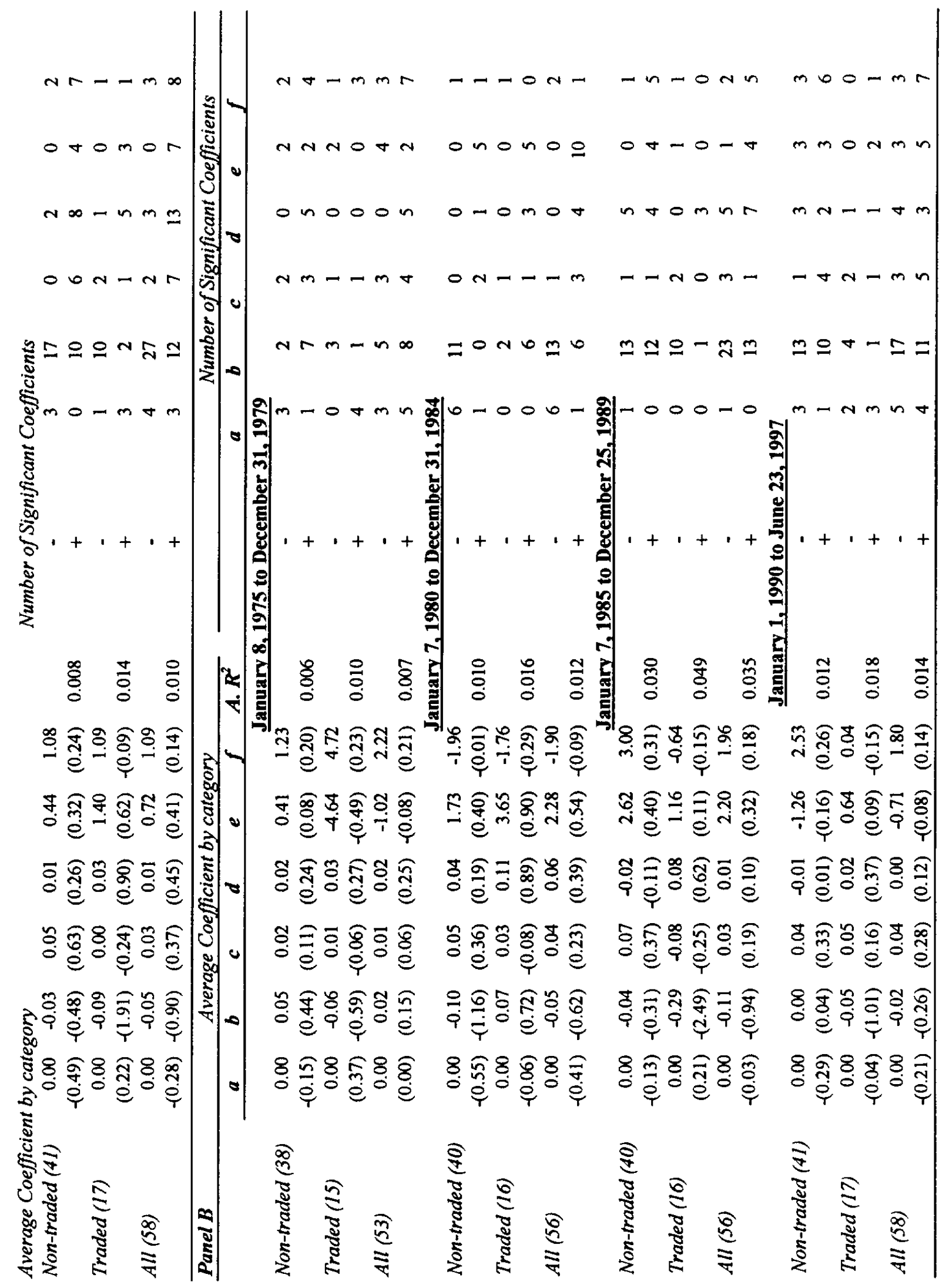


traded goods industries. However, they do not have a significant impact on our assessment of competitive effects.

To investigate whether different regression specifications lead to different assessments of the importance of exchange rate and industry effects, we also allow for several other nonlinear measures of exchange rate volatility. First, we use the average standard deviation from daily exchange rate changes during the week as our proxy for return volatility. Similar to regressions in Table IV, this measure of volatility does not seem to add to our basic specification. A second alternative way to measure the volatility is to estimate an autoregressive conditional heteroskedasticity model of the absolute value of the exchange rate projected onto past value $(\mathrm{ARCH}(1))$. The absolute value of the exchange rate can then be composed of an expected and unexpected component. The fitted values from this regression do not add to our understanding of industry effects because the standard deviation of the expected volatility series is only around onetenth of the other exchange rate measures. Our final measure is the residual from the ARCH(1) regression. These residuals are highly correlated with the underlying absolute value of the exchange rate and thus inferences are extremely similar whether this series or the absolute value of the exchange rate is used. Most of our results in the remainder of the paper will simply focus on the regressions estimated in section 3 because the regressions discussed in this section do not alter our conclusions.

\section{Competitive effects across countries.}

We now consider regressions similar to those of section 3 using the other countries in our sample as well as using the U.S. industry as the dependent variable. There are too many such regressions for us to report individual results. We therefore report summary statistics in Table V 
and plot the coefficients, their t-statistics and the adjusted $R^{2}$ s in Figure 2. For completeness, we include the results for Japan discussed in section 3 as well. The results for the U.S. use the yen price of the dollar to compute the exchange rate return. This implies that in all our regressions a positive exchange rate return corresponds to an appreciation of the local currency relative to the currency of the foreign country and therefore we can average coefficients across countries.

The results for the world are striking. We have 320 industry pairs. For these industry pairs, the average adjusted $R^{2}$ is $0.4 \%$ for the regressions without industry excess returns. Interestingly, taking into account the industry excess returns increases the adjusted $R^{2}$ to one percent. The average exchange rate slope coefficient is -0.01 . Across the 320 industries, the significant positive and negative exchange rate slope coefficients are about evenly balanced since we have 55 negative coefficients and 59 positive ones. More importantly, Figure 2 demonstrates that for most industries the relative magnitude of the exchange rate coefficients are small, indicating that exchange rate movements typically cannot explain large amounts of cross-sectional differences in industry performance. Of the 320 industries, only 26 or 8.1 percent have exchange rate coefficients that are above 0.3 or below -0.3 . Traded goods industries are more likely to have a negative coefficient and non-traded goods industries are more likely to have a positive coefficient. Industry effects are generally positive and significantly so for 89 industry pairs. Only 6 industry pairs have a significantly negative industry slope coefficient. The industry effects explain more for traded goods industries than for non-traded goods industries. For traded goods industries, the average adjusted $R^{2}$ increases from $0.3 \%$ to $2.1 \%$ as the excess return of the foreign industry is added. In contrast, the average adjusted $R^{2}$ of the non-traded goods industries increases from $0.4 \%$ to $0.6 \%$. 
Table V. Industry Excess Weekly Returns Regressed on the Exchange rate and the U.S. Industry Excess Returns from January 8, 1975 to June 23, 1997 for all Countries in the Sample

For Japan, the UK, Germany, France, Canada and the U.S., coefficient estimates, $t$-statistics (below coefficients), and adjusted $R^{2}$ are presented from regressions over the period from January 8, 1975 to June 23,1997 . The local currency denominated industry return in excess of the corresponding local weekly market return $\left(r_{i}=R_{i}-R_{M}\right)$ is regressed on the dollar/currency exchange rate or both the exchange rate and the U.S. industry return in excess of the value-weighted U.S. market return $\left(r_{U S i}=R_{U S i}-R_{U S M}\right)$. For market indices the returns are not excess returns. For the U.S. regressions the foreign market excess industry return is from Japan. The number in parenthesis corresponds to the number of traded, non-traded or total industries within a country. The number of coefficients that are significantly positive at the upper and lower five percent level for traded and non-traded industries is also presented. The OLS regressions with the exchange rate and the industry returns in excess of their respective market return are as follows:

\begin{tabular}{|c|c|c|c|c|c|c|c|c|c|c|c|c|c|}
\hline & \multicolumn{6}{|c|}{ World } & & \multicolumn{6}{|c|}{$\begin{array}{c}\text { United States } \\
\end{array}$} \\
\hline & \multicolumn{4}{|c|}{ Average Coefficient } & \multicolumn{2}{|c|}{ No. Sign. } & & \multicolumn{4}{|c|}{ Average Coefficient } & \multicolumn{2}{|c|}{ No. Sign. } \\
\hline & $a$ & $\boldsymbol{b}$ & $d$ & adj. $R^{2}$ & $a b$ & $b d$ & & $a$ & $\boldsymbol{b}$ & $d$ & $\operatorname{adj} . R^{2}$ & $a b$ & $d$ \\
\hline$N-\operatorname{Tr} a$ & 0.00 & 0.00 & & & -63 & 34 & $N-\operatorname{Tr} a(41)$ & 0.00 & 0.02 & & & 11 & \\
\hline \multirow{3}{*}{$(220)$} & $(0.11)$ & $(0.27)$ & & 0.004 & 85 & & & $(0.25)$ & $(0.37)$ & & 0.000 & 34 & \\
\hline & 0.00 & 0.00 & 0.03 & & 53 & 334 & & 0.00 & 0.02 & 0.02 & & 10 & 0 \\
\hline & $(0.11)$ & $(0.28)$ & $(0.80)$ & 0.006 & +85 & 5148 & & $(0.25)$ & $(0.39)$ & $(0.64)$ & 0.000 & 34 & 7 \\
\hline Trad & 0.00 & -0.03 & & & -52 & & Trad (17) & 0.00 & -0.01 & & & 20 & \\
\hline \multirow[t]{3}{*}{$(100)$} & $-(0.14)$ & $-(0.63)$ & & 0.003 & +6 & 9 & & $-(0.31)$ & $-(0.25)$ & & -0.001 & + & \\
\hline & 0.00 & -0.04 & 0.08 & & -52 & 222 & & 0.00 & -0.01 & 0.03 & & - & 1 \\
\hline & $-(0.11)$ & $-(0.73)$ & (2.46) & 0.021 & +48 & 841 & & $-(0.32)$ & $-(0.32)$ & $(1.31)$ & 0.004 & 10 & 6 \\
\hline \multirow{5}{*}{ All (320) } & 0.00 & -0.01 & & & -115 & & All (58) & 0.00 & 0.01 & & & 31 & \\
\hline & $(0.03)$ & $-(0.01)$ & & 0.004 & +1460 & & & $(0.09)$ & $(0.19)$ & & 0.000 & + & \\
\hline & 0.00 & -0.01 & 0.05 & & -105 & 556 & & 0.00 & 0.01 & 0.02 & & 30 & 1 \\
\hline & $(0.04)$ & $-(0.03)$ & (1.31) & 0.010 & +125 & & & $(0.09)$ & $(0.18)$ & $(0.84)$ & 0.001 & +441 & 13 \\
\hline & \multicolumn{6}{|c|}{ Japan } & & \multicolumn{6}{|c|}{ United Kingdom } \\
\hline \multirow[t]{4}{*}{$N-\operatorname{Tr} a(41)$} & 0.00 & -0.02 & & & 01 & & $N-\operatorname{Tr} a(46)$ & 0.00 & 0.04 & & & 14 & \\
\hline & $-(0.03)$ & $-(0.33)$ & & 0.007 & 11 & & & $(0.09)$ & $(0.81)$ & & 0.006 & 115 & \\
\hline & 0.00 & -0.02 & 0.02 & & 016 & 160 & & 0.00 & 0.04 & 0.04 & & 14 & 0 \\
\hline & $-(0.03)$ & $-(0.33)$ & $(0.64)$ & 0.008 & 111 & 117 & & $(0.09)$ & $(0.83)$ & $(0.98)$ & 0.008 & +115 & 12 \\
\hline \multirow[t]{4}{*}{ Trad (17) } & 0.00 & -0.09 & & & -09 & 9 & Trad (19) & 0.00 & -0.03 & & & -16 & \\
\hline & $(0.03)$ & $-(2.05)$ & & 0.009 & +0 & 2 & & $-(0.20)$ & $-(0.77)$ & & 0.005 & +13 & \\
\hline & 0.00 & -0.09 & 0.04 & & -0 & 91 & & 0.00 & -0.03 & 0.12 & & -16 & 0 \\
\hline & $(0.04)$ & $-(2.05)$ & (1.31) & 0.013 & +02 & 26 & & $-(0.15)$ & $-(0.91)$ & $(3.22)$ & 0.028 & +13 & 11 \\
\hline \multirow[t]{4}{*}{ All (58) } & 0.00 & -0.04 & & & -025 & & All (65) & 0.00 & 0.02 & & & -210 & \\
\hline & $-(0.01)$ & $-(0.83)$ & & 0.008 & +113 & & & $(0.01)$ & $(0.35)$ & & 0.005 & +218 & \\
\hline & 0.00 & -0.04 & 0.03 & & -025 & 251 & & 0.00 & 0.02 & 0.06 & & -210 & 0 \\
\hline & $-(0.01)$ & $-(0.83)$ & $(0.84)$ & 0.009 & +113 & 1313 & & $(0.02)$ & $(0.32)$ & $(1.63)$ & 0.014 & +218 & 23 \\
\hline
\end{tabular}




\begin{tabular}{|c|c|c|c|c|c|c|c|c|c|c|c|c|c|c|c|}
\hline \multirow[b]{2}{*}{$N-\operatorname{Tr} a(24)$} & \multicolumn{7}{|c|}{ Germany } & & \multicolumn{7}{|c|}{ France } \\
\hline & 0.00 & 0.08 & & & - & 1 & 2 & $N-\operatorname{Tr} a(33)$ & 0.00 & 0.02 & & & -2 & 5 & \\
\hline \multirow{7}{*}{ Trad (15) } & $-(0.31)$ & $(1.24)$ & & 0.005 & + & 11 & & & $(0.13)$ & $(0.27)$ & & 0.003 & +1 & 6 & \\
\hline & 0.00 & 0.08 & 0.02 & & - & & 21 & & 0.00 & 0.02 & 0.00 & & -2 & 5 & \\
\hline & $-(0.31)$ & $(1.24)$ & $(0.35)$ & 0.005 & + & 11 & 114 & & $(0.12)$ & $(0.26)$ & $(0.08)$ & 0.003 & +1 & 6 & 3 \\
\hline & 0.00 & 0.05 & & & - & 1 & 3 & Trad (15) & 0.00 & -0.02 & & & -0 & 1 & \\
\hline & $-(0.19)$ & $-(0.26)$ & & 0.004 & + & 2 & 2 & & $-(0.37)$ & $-(0.11)$ & & -0.001 & +0 & 1 & \\
\hline & 0.00 & 0.05 & 0.02 & & - & 1 & 30 & & 0.00 & 0.00 & 0.05 & & -0 & 1 & 0 \\
\hline & $-(0.20)$ & $-(0.24)$ & $(0.71)$ & 0.006 & + & 2 & 23 & & $-(0.34)$ & $-(0.05)$ & $(0.96)$ & 0.004 & +0 & 1 & 2 \\
\hline \multirow[t]{5}{*}{ All (39) } & 0.00 & 0.06 & & & - & 2 & 5 & All (48) & 0.00 & 0.01 & & & -2 & 6 & \\
\hline & $-(0.26)$ & $(0.66)$ & & 0.005 & + & 31 & 13 & & $-(0.03)$ & $(0.16)$ & & 0.002 & +1 & 7 & \\
\hline & 0.00 & 0.07 & 0.02 & & - & 2 & 51 & & 0.00 & 0.01 & 0.01 & & -2 & & 1 \\
\hline & $-(0.27)$ & $(0.67)$ & $(0.49)$ & 0.006 & + & 31 & 137 & & $-(0.02)$ & $(0.17)$ & $(0.35)$ & 0.003 & +1 & & 5 \\
\hline & & & Can & da & & & & & & & & & & & \\
\hline \multirow[t]{4}{*}{$N$-Tra(35) } & 0.00 & -0.13 & & & - & 1 & 6 & & & & & & & & \\
\hline & $(0.40)$ & $-(0.50)$ & & 0.002 & + & 1 & 4 & & & & & & & & \\
\hline & 0.00 & -0.13 & 0.11 & & - & 0 & 62 & & & & & & & & \\
\hline & $(0.42)$ & $-(0.49)$ & $(1.91)$ & 0.009 & + & 1 & 415 & & & & & & & & \\
\hline \multirow[t]{4}{*}{$\operatorname{Trad}(17)$} & 0.00 & -0.07 & & & - & 1 & 2 & & & & & & & & \\
\hline & $(0.17)$ & $-(0.25)$ & & 0.001 & + & 2 & 1 & & & & & & & & \\
\hline & 0.00 & -0.12 & 0.21 & & - & 1 & 30 & & & & & & & & \\
\hline & $(0.28)$ & $-(0.61)$ & $(6.67)$ & 0.065 & + & 0 & 013 & & & & & & & & \\
\hline \multirow[t]{4}{*}{$A l l(52)$} & 0.00 & -0.11 & & & $\cdot$ & 2 & 8 & & & & & & & & \\
\hline & $(0.32)$ & $-(0.42)$ & & 0.001 & + & 3 & 5 & & & & & & & & \\
\hline & 0.00 & -0.13 & 0.14 & & - & 1 & 92 & & & & & & & & \\
\hline & $(0.37)$ & $-(0.53)$ & $(3.46)$ & 0.027 & + & 1 & 428 & & & & & & & & \\
\hline
\end{tabular}


There is no symmetry between the results for U.S. industries and for Japanese industries for the exchange rate slope coefficients. Looking at the regressions with only the exchange rate returns, the average exchange rate slope coefficient for the traded goods industries in Japan is 0.09 whereas the average slope coefficient for the same industries in the U.S. is -0.01 . The highest exchange rate slope coefficient for the whole sample for a U.S. industry is 0.10 . No adjusted $R^{2}$ exceeds $0.7 \%$ and the average adjusted $R^{2}$ is approximately zero when the industry effects are not included. The automotive assembly industry has a slope coefficient of -0.01 and an adjusted $R^{2}$ of $-0.1 \%$. The industry effects are equally small with only one industry having a coefficient in excess of 0.1 , the fund management industry with a coefficient of 0.13 .

For the other countries, the exchange rate returns generally have little impact. The average exchange rate slope coefficient for traded goods industries is highest in absolute value in Canada followed by Japan. Canada has the largest slope for the non-traded goods industries in absolute value also, but the average slope is negative whereas in all other countries except Japan it is positive. Interestingly, in the UK, Germany, France and the U.S. the non-traded goods industries have more significant positive coefficients than negative coefficients. Generally, traded goods industries have more significant negative coefficients than positive ones. However, the U.S. has no significant coefficient for traded goods industries, indicating again that the U.S. is an extreme case. A useful way to understand the effect of exchange rates is to note that no regression with the exchange rate only for the U.S has an adjusted $R^{2}$ in excess of one percent. For Canada, France, Germany, the UK, and Japan, respectively 1, 2, 5, 12, and 14 industries have adjusted $R^{2} \mathrm{~s}$ in excess of one percent. Using this measure, exchange rate effects are most important in Japan. 
Figure 2. Distribution of the summary statistics for regressions of industry excess weekly returns in the U.S., Japan, the UK, Germany, France, and Canada regressed on the Yen/dollar exchange rate and the U.S. industry (or Japanese industry for U.S. industries) excess return. Plots for the coefficient estimates, the t-statistics, and the adj. $R^{2} s$ are shown below for traded and non-traded goods industries for the period January 8, 1975 to May 23, 1997.

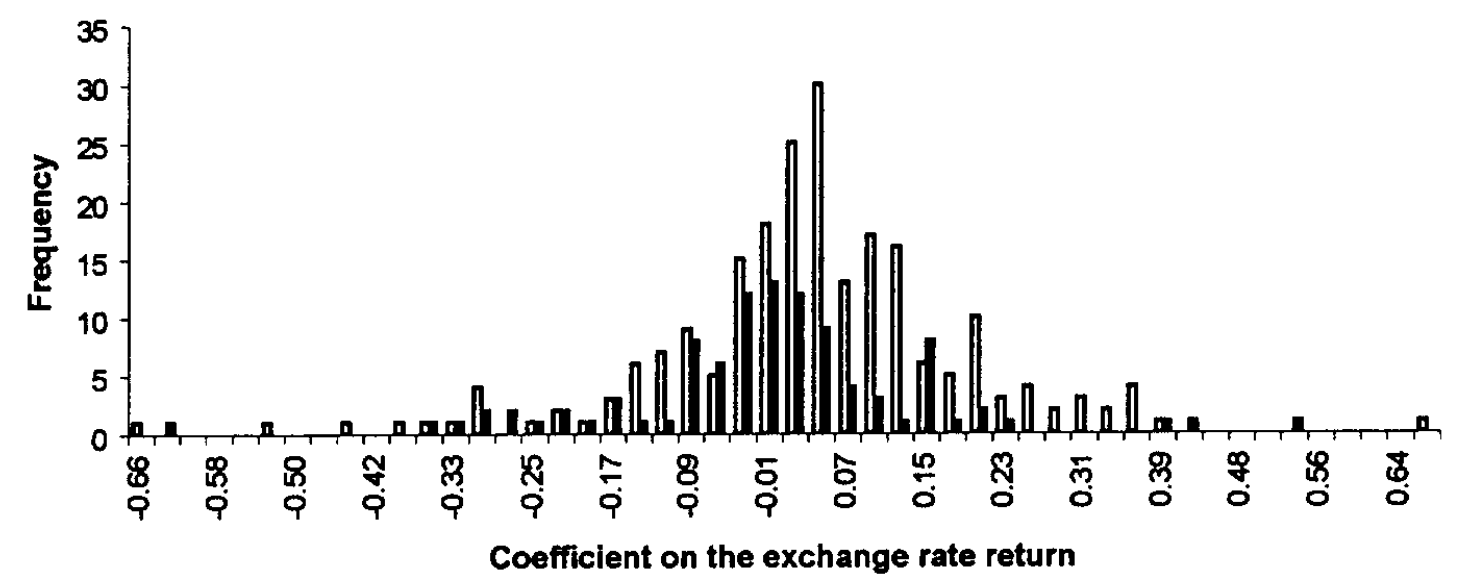

$\square_{\text {Non-Traded }} \mathbf{T r a d e d}$

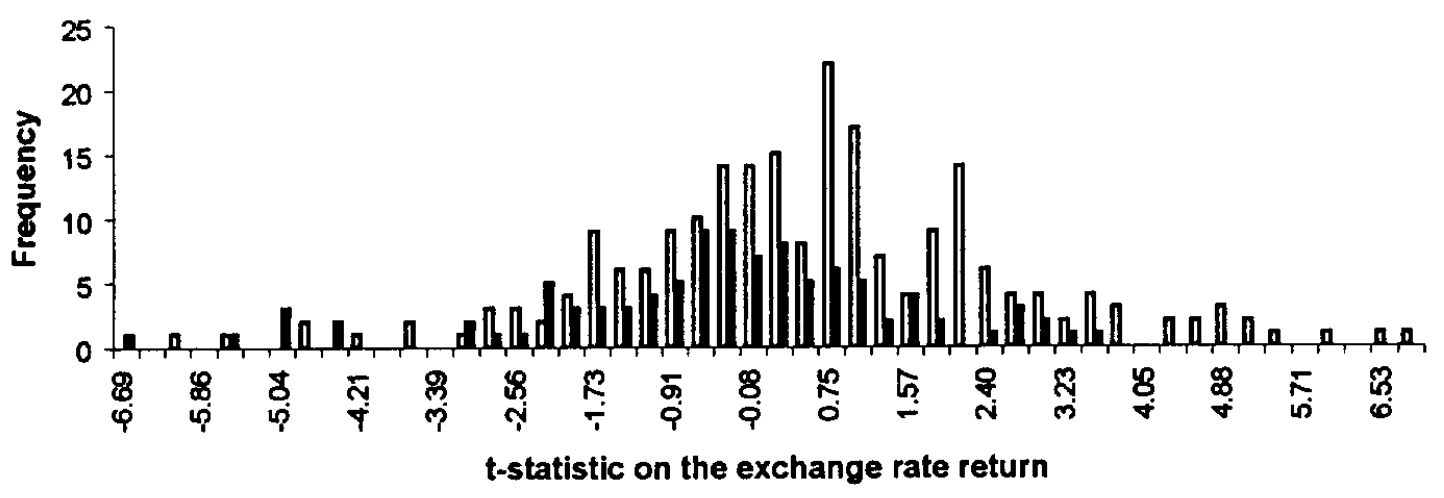

$\square$ Non-Traded $\mathbf{\square}$ Traded 

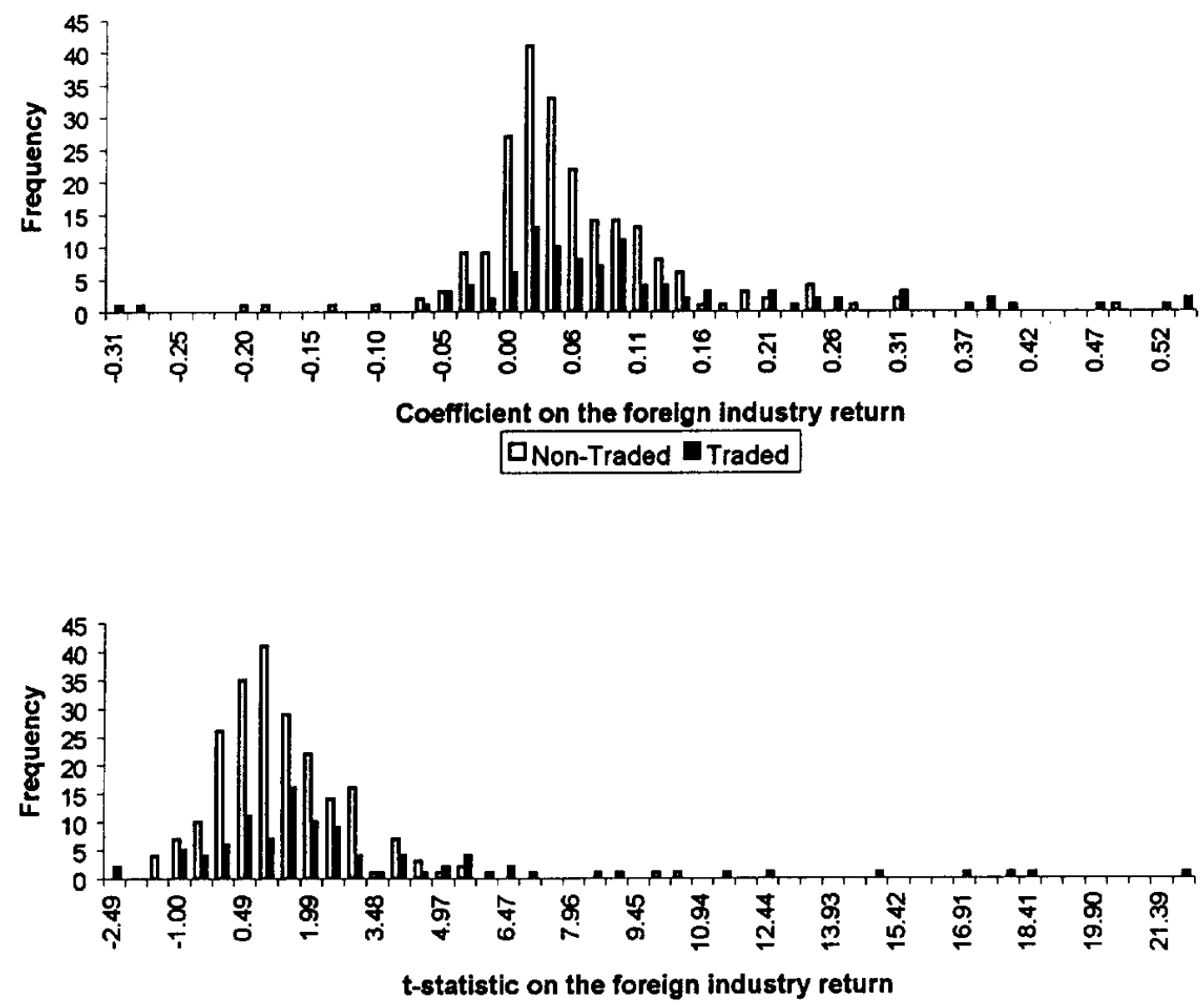

\section{$\square$ Non-Traded $\square$ Traded}

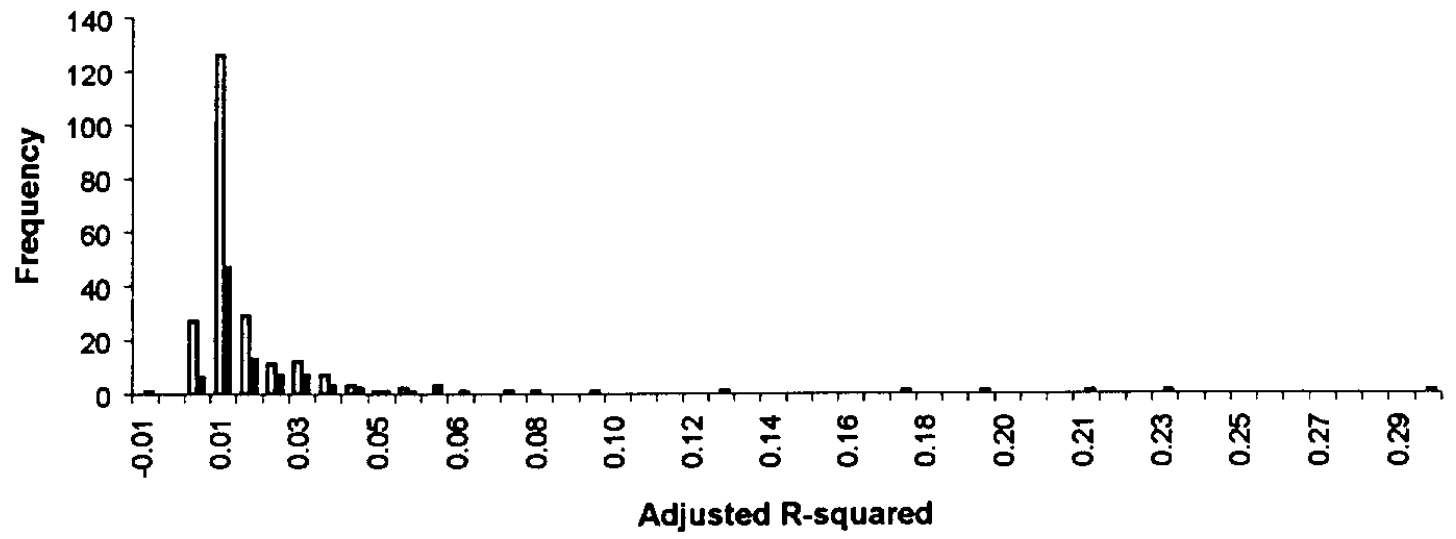

DNon-Traded $\mathbf{T r a d e d}$ 
We saw in our discussion of the Japanese results that exposures were larger during the period from 1985 to 1989 and noted that during this period the yen appreciated sharply. It is interesting to note that during that period the DM and the French franc also sharply appreciated. The exchange rate returns do not explain more during that period for French industries. For German industries, exchange rate exposures explain slightly more for non-traded goods industries.

The average slope coefficient for non-traded industries is 0.13 with an adjusted $R^{2}$ of $1.7 \%$. 12 German industries have an adjusted $R^{2}$ in excess of $1 \%$, but none has an adjusted $R^{2}$ in excess of $10 \%$. Consequently, it may well be that the sharp appreciation of the yen explains why the 1985 to 1989 period has unique characteristics in Japan, but the equally sharp appreciation for some European currencies does not make that period stand out for their countries.

Our sample period covers a long period of time where the importance of international trade grew dramatically and financial markets became much more integrated. It could therefore be that our results for the whole sample period are not representative of the current importance of industry and exchange rate shocks. However, results for the 1990s are remarkably similar for those of the whole sample period. The exception is Canada, where industry effects increased for the traded goods industry. For all other countries, the results for the whole sample are not distinguishable from results for the 1990s.

Bartov and Bodnar (1994) show that lag exchange rate changes are significantly related to stock returns for a subset of U.S. firms and Allyannis (1996) finds that exchange rate exposures grow when one measures returns over longer periods of time. We investigate in Tables VI and VII whether our conclusions are affected using quarterly or yearly data. In results not reported here, we also estimate our regressions on monthly data. Looking at all industries together, we see that for the traded and non-traded goods industries, exchange rate shocks explain more of the 
Table VI. All countries: Industry Excess Quarterly Returns Regressed on the Exchange rate and the U.S. Industry Excess Returns.

For Japan, the UK, Germany, France, Canada and the U.S., coefficient estimates, $t$-statistics (below coefficients), and adjusted $R^{2} s$ are presented from regressions over the period from January 8, 1975 to June 23,1997 . The local currency denominated industry return in excess of the corresponding local quarterly market return $\left(r_{i}=R_{i}-R_{M}\right)$ is regressed on the dollar/currency exchange and the U.S. industry return in excess of the value-weighted U.S. market return $\left(r_{U S i}=R_{U S i}-R_{U S M}\right)$. For market indices the returns are not excess returns. For the U.S. regressions the foreign market excess industry return is from Japan. The number in parenthesis corresponds to the number of traded, non-traded or total industries within a country. The number of coefficients that are significantly positive at the upper and lower five percent level for traded and non-traded industries is also presented. The OLS regressions with the exchange rate and the industry returns in excess of their respective market return are as follows:

\begin{tabular}{|c|c|c|c|c|c|c|c|c|c|c|c|c|c|c|}
\hline & \multicolumn{7}{|c|}{ World } & \multicolumn{7}{|c|}{ United States } \\
\hline & \multicolumn{4}{|c|}{ Average Coefficient } & \multirow{2}{*}{\multicolumn{2}{|c|}{ No. Sign. }} & & \multicolumn{4}{|c|}{ Average Coefficient } & \multirow{2}{*}{\multicolumn{3}{|c|}{ No. Sign. }} \\
\hline & & & & & & & & & & & & & & \\
\hline & 0.00 & -0.01 & & & 818 & & $N-\operatorname{Tra}(41)$ & 0.00 & 0.01 & & & & 1 & \\
\hline \multirow[t]{3}{*}{ (214) } & $(0.10)$ & $(0.09)$ & & 0.008 & +1221 & & & $(0.19)$ & $(0.16)$ & & -0.006 & & 3 & \\
\hline & 0.00 & -0.01 & 0.08 & & -819 & & & 0.00 & 0.02 & 0.03 & & & 1 & 5 \\
\hline & $(0.09)$ & $(0.12)$ & $(0.64)$ & 0.023 & +1024 & 48 & & $(0.20)$ & $(0.19)$ & $(0.34)$ & 0.014 & & & 10 \\
\hline Trad & 0.00 & -0.07 & & & -417 & & $\operatorname{Trad}(17)$ & 0.00 & 0.00 & & & & 2 & \\
\hline \multirow[t]{3}{*}{ (93) } & $-(0.17)$ & $-(0.44)$ & & 0.009 & +37 & & & $-(0.32)$ & $-(0.03)$ & & -0.001 & & 1 & \\
\hline & 0.00 & -0.10 & 0.18 & & -318 & 0 & & 0.00 & -0.01 & 0.03 & & & 2 & 0 \\
\hline & $-(0.14)$ & $-(0.54)$ & $(1.45)$ & 0.052 & +25 & 28 & & $-(0.34)$ & $-(0.12)$ & $(0.45)$ & 0.002 & + & 1 & 2 \\
\hline \multirow[t]{5}{*}{ All (307) } & 0.00 & -0.03 & & & -1235 & & All (58) & 0.00 & 0.01 & & & & 3 & \\
\hline & $(0.02)$ & $-(0.07)$ & & 0.008 & +1528 & & & $(0.04)$ & $(0.10)$ & & -0.005 & + & 4 & \\
\hline & 0.00 & -0.03 & 0.11 & & -1137 & & & 0.00 & 0.01 & 0.03 & & & 3 & 5 \\
\hline & $(0.02)$ & $-(0.08)$ & $(0.89)$ & 0.032 & +1229 & & & $(0.04)$ & $(0.10)$ & $(0.37)$ & 0.011 & & & 12 \\
\hline & & & Jap & an & & & & & & nited $\mathbf{F}$ & Kingdom & & & \\
\hline \multirow[t]{4}{*}{$N-\operatorname{Tr} a(41)$} & 0.00 & -0.01 & & & 07 & & $N-\operatorname{Tr} a(45)$ & 0.00 & 0.05 & & & & 1 & \\
\hline & $-(0.07)$ & $(0.04)$ & & 0.016 & +18 & & & $(0.11)$ & $(0.32)$ & & 0.006 & + & 1 & \\
\hline & 0.00 & -0.01 & 0.04 & & -07 & 5 & & 0.00 & 0.07 & 0.14 & & - & 1 & 1 \\
\hline & $-(0.11)$ & $(0.04)$ & $(0.34)$ & 0.036 & +18 & 10 & & $(0.08)$ & $(0.38)$ & $(1.08)$ & 0.023 & + & 1 & 11 \\
\hline \multirow[t]{4}{*}{ Trad (17) } & 0.00 & -0.18 & & & -06 & & Trad (18) & 0.00 & -0.15 & & & - & 0 & \\
\hline & $(0.09)$ & $-(1.00)$ & & 0.012 & +00 & & & $-(0.27)$ & $-(0.96)$ & & 0.021 & & 0 & \\
\hline & 0.00 & -0.19 & 0.05 & & -06 & 50 & & 0.00 & -0.18 & 0.30 & & - & 0 & 0 \\
\hline & $(0.14)$ & $-(0.99)$ & $(0.45)$ & 0.015 & +00 & 2 & & $-(0.21)$ & $-(1.20)$ & (2.41) & 0.103 & + & 0 & 7 \\
\hline \multirow[t]{4}{*}{ All (58) } & 0.00 & -0.06 & & & - 013 & & All (63) & 0.00 & 0.00 & & & - & 1 & \\
\hline & $-(0.02)$ & $-(0.27)$ & & 0.015 & +18 & & & $(0.00)$ & $-(0.04)$ & & 0.010 & + & 1 & \\
\hline & 0.00 & -0.06 & 0.05 & & -013 & 5 & & 0.00 & -0.01 & 0.19 & & - & 1 & 1 \\
\hline & $-(0.04)$ & $-(0.26)$ & $(0.37)$ & 0.030 & +18 & 12 & & $(0.00)$ & $-(0.07)$ & (1.46) & 0.046 & +1 & 1 & 18 \\
\hline
\end{tabular}




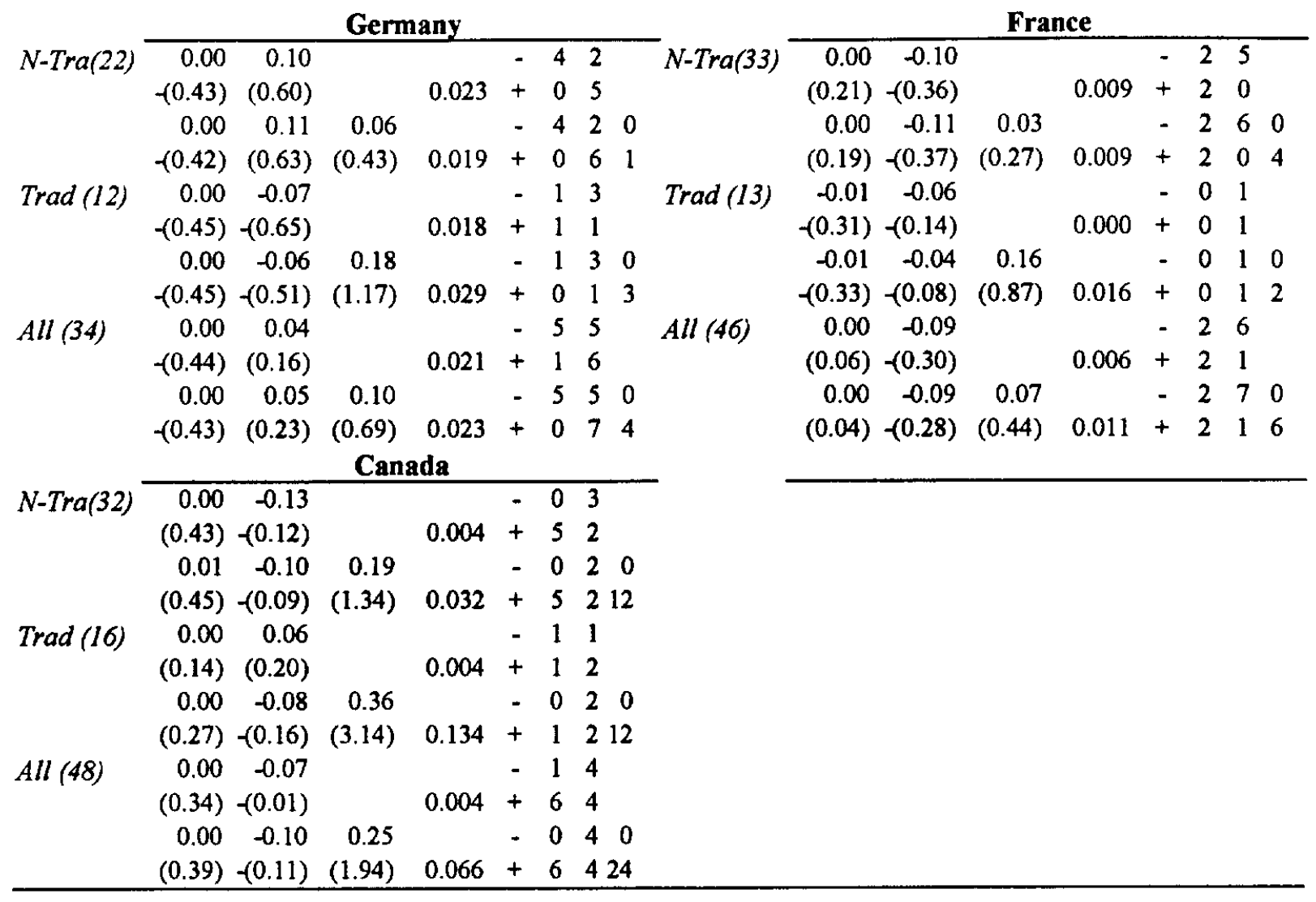



Table VII. All countries: Industry Excess Yearly Returns Regressed on the Exchange rate
and the U.S. Industry Excess Returns.

For Japan, the UK, Germany, France, Canada and the U.S., coefficient estimates, $t$-statistics (below coefficients), and adjusted $R^{2} s$ are presented from regressions over the period from January 8,1975 to June 23, 1997. The local currency denominated industry return in excess of the corresponding local yearly market return $\left(r_{i}=R_{i}-R_{M}\right)$ is regressed on the dollar/currency exchange rate and the U.S. industry return in excess of the value-weighted U.S. market return $\left(r_{U S t}=R_{U S i}-R_{U S M}\right)$. For market indices the returns are not excess returns. For the U.S. regressions the foreign market excess industry return is from Japan. The number in parenthesis corresponds to the number of traded, non-traded or total industries within a country. The number of coefficients that are significantly positive at the upper and lower five percent level for traded and non-traded industries is also presented. The OLS regressions with the exchange rate and the industry returns in excess of their respective market return are as follows:

\begin{tabular}{|c|c|c|c|c|c|c|c|c|c|c|c|c|c|c|c|c|c|}
\hline & & & Wo & orld & & & & & & & & United & States & & & & \\
\hline & & erage $C$ & Coefficie & ent & & No. & Sign & & & & erage $C$ & Coeffici & & & o. & Sign & \\
\hline & $a$ & $b$ & $d$ & $\operatorname{adj} . R^{2}$ & & $a$ & $b$ & & & $a$ & $b$ & $d$ & $\overline{a d j .} R^{2}$ & & $\bar{a}$ & $b a$ & $d$ \\
\hline$N-\operatorname{Tr} a$ & 0.00 & -0.01 & & & & - 10 & 14 & & $N-\operatorname{Tr} a(38)$ & 0.00 & 0.00 & & & - & 3 & 0 & \\
\hline (181) & $(0.01)$ & $(0.11)$ & & 0.014 & + & 5 & 18 & & & $(0.03)$ & $-(0.01)$ & & -0.016 & + & 3 & 0 & \\
\hline & 0.00 & 0.02 & 0.08 & & . & 9 & 121 & & & 0.00 & 0.01 & -0.08 & & - & 3 & 0 & 4 \\
\hline & $-(0.01)$ & $(0.19)$ & $(0.31)$ & 0.031 & + & 3 & 182 & & & $(0.08)$ & $(0.04)$ & $-(0.16)$ & -0.009 & + & 2 & 12 & 2 \\
\hline Trad & -0.01 & -0.13 & & & . & 1 & 9 & & Trad (15) & -0.01 & 0.03 & & & & 0 & 0 & \\
\hline (81) & $-(0.15)$ & $-(0.36)$ & & 0.016 & + & -1 & 4 & & & $-(0.23)$ & $(0.10)$ & & -0.017 & + & 0 & 0 & \\
\hline & -0.01 & -0.21 & 0.32 & & & 0 & 12 & 2 & & -0.01 & -0.07 & 0.32 & & - & 0 & 0 & 0 \\
\hline & $-(0.11)$ & $-(0.52)$ & (1.33) & 0.103 & + & -1 & 42 & & & $-(0.29)$ & $-(0.18)$ & $(1.25)$ & 0.046 & + & 0 & & 5 \\
\hline All (262) & 0.00 & -0.05 & & & & 11 & & & All (53) & 0.00 & 0.01 & & & - & 3 & 0 & \\
\hline & $-(0.04)$ & $-(0.03)$ & & 0.015 & + & 6 & 22 & & & $-(0.05)$ & $(0.02)$ & & -0.017 & + & 3 & 0 & \\
\hline & 0.00 & -0.05 & 0.15 & & . & 9 & 241 & & & 0.00 & -0.02 & 0.03 & & - & 3 & 0 & 4 \\
\hline & $-(0.04)$ & $-(0.03)$ & $(0.63)$ & 0.053 & + & & 225 & & & $-(0.03)$ & $-(0.02)$ & $(0.24)$ & 0.007 & + & 2 & 1 & 7 \\
\hline & & & $\mathrm{Jap}$ & pan & & & & & & & & Inited $\mathbf{Y}$ & Kingdom & & & & \\
\hline$N-\operatorname{Tra}(38)$ & 0.00 & 0.05 & & & - & 0 & 3 & & $N-\operatorname{Tr} a(40)$ & 0.00 & 0.15 & & & & 1 & 3 & \\
\hline & $-(0.04)$ & $(0.24)$ & & 0.036 & + & 2 & 7 & & & $(0.00)$ & $(0.48)$ & & 0.023 & + & 0 & 7 & \\
\hline & 0.00 & 0.07 & 0.02 & & . & 0 & 2 & 4 & & 0.00 & 0.17 & 0.23 & & - & 1 & & 1 \\
\hline & $-(0.09)$ & $(0.26)$ & $-(0.16)$ & 0.044 & + & -1 & 6 & 2 & & $-(0.08)$ & $(0.52)$ & $(0.97)$ & 0.065 & + & 0 & 710 & \\
\hline Trad (15) & 0.01 & -0.28 & & & . & 0 & 4 & & Trad (17) & -0.01 & -0.09 & & & - & 0 & 4 & \\
\hline & $(0.37)$ & $-(0.88)$ & & 0.036 & + & 1 & 0 & & & $-(0.30)$ & $-(0.55)$ & & 0.060 & + & 0 & 2 & \\
\hline & 0.01 & -0.25 & 0.27 & & . & 0 & 4 & 0 & & -0.01 & -0.14 & 0.34 & & - & 0 & 42 & 2 \\
\hline & $(0.45)$ & $-(0.86)$ & $(1.25)$ & 0.093 & + & 1 & 0 & 5 & & $-(0.31)$ & $-(0.79)$ & $(1.49)$ & 0.198 & + & 0 & 2 & 5 \\
\hline All (53) & 0.00 & -0.04 & & & . & 0 & 7 & & All (57) & 0.00 & 0.07 & & & - & 1 & 7 & \\
\hline & $(0.07)$ & $-(0.08)$ & & 0.036 & + & 3 & 7 & & & $-(0.09)$ & $(0.17)$ & & 0.034 & + & 0 & 9 & \\
\hline & 0.00 & -0.02 & 0.09 & & - & 0 & 6 & 4 & & 0.00 & 0.08 & 0.26 & & - & 1 & 7 & 3 \\
\hline & $(0.06)$ & $-(0.06)$ & $(0.24)$ & 0.058 & + & 2 & 6 & 7 & & $-(0.14)$ & $(0.14)$ & (1.12) & 0.103 & & 0 & & 15 \\
\hline
\end{tabular}




\begin{tabular}{|c|c|c|c|c|c|c|c|c|c|c|c|c|c|c|c|}
\hline \multirow[b]{2}{*}{$N-\operatorname{Tr} a(18)$} & \multicolumn{7}{|c|}{ Germany } & & \multicolumn{7}{|c|}{ France } \\
\hline & -0.02 & 0.09 & & & - & 5 & 2 & N-Tra(22) & 0.01 & -0.16 & & & -0 & & \\
\hline & $-(0.55)$ & $(0.50)$ & & 0.020 & + & 0 & 4 & & $(0.15)$ & $-(0.38)$ & & 0.033 & +0 & 0 & \\
\hline & -0.02 & 0.14 & 0.10 & & - & 5 & 11 & & 0.01 & -0.08 & 0.10 & & -0 & & 0 \\
\hline & $-(0.50)$ & $(0.64)$ & $(0.53)$ & 0.046 & + & 0 & 32 & & $(0.10)$ & $-(0.22)$ & $(0.21)$ & 0.031 & +0 & 0 & 3 \\
\hline \multirow[t]{4}{*}{ Trad (10) } & -0.02 & -0.21 & & & - & 0 & 1 & Trad (10) & -0.02 & 0.08 & & & -0 & 0 & \\
\hline & $-(0.51)$ & $-(0.79)$ & & 0.001 & + & 0 & 0 & & $-(0.13)$ & $(0.34)$ & & 0.008 & +0 & 1 & \\
\hline & -0.02 & -0.24 & 0.21 & & - & 0 & 10 & & -0.02 & 0.12 & 0.25 & & -0 & & 0 \\
\hline & $-(0.49)$ & $-(0.87)$ & $(0.94)$ & 0.015 & + & 0 & 02 & & $-(0.14)$ & $(0.45)$ & $(0.77)$ & 0.056 & +0 & & 2 \\
\hline \multirow[t]{5}{*}{ All (28) } & -0.02 & -0.02 & & & - & 5 & 3 & All (32) & 0.00 & -0.08 & & & -0 & 3 & \\
\hline & $-(0.53)$ & $(0.04)$ & & 0.013 & + & 0 & 4 & & $(0.07)$ & $-(0.16)$ & & 0.025 & +0 & 1 & \\
\hline & -0.02 & 0.00 & 0.14 & & - & 5 & 21 & & 0.00 & -0.02 & 0.15 & & -0 & & 0 \\
\hline & $-(0.50)$ & $(0.10)$ & $(0.67)$ & 0.035 & + & 0 & 34 & & $(0.02)$ & $(0.00)$ & $(0.39)$ & 0.039 & +0 & & 5 \\
\hline & & & Can & ada & & & & & & & & & & & \\
\hline \multirow[t]{4}{*}{$N-\operatorname{Tr} a(25)$} & 0.01 & -0.33 & & & - & 1 & 3 & & & & & & & & \\
\hline & $(0.35)$ & $-(0.34)$ & & -0.009 & + & 0 & 0 & & & & & & & & \\
\hline & 0.01 & -0.28 & 0.14 & & - & 0 & 30 & & & & & & & & \\
\hline & $(0.33)$ & $-(0.23)$ & $(0.64)$ & 0.005 & + & 0 & 15 & & & & & & & & \\
\hline \multirow[t]{4}{*}{ Trad (14) } & -0.01 & -0.30 & & & - & 1 & 0 & & & & & & & & \\
\hline & $-(0.18)$ & $-(0.25)$ & & -0.005 & + & 0 & 1 & & & & & & & & \\
\hline & 0.00 & -0.60 & 0.50 & & - & 0 & 30 & & & & & & & & \\
\hline & $(0.00)$ & $-(0.68)$ & (2.01) & 0.166 & + & 0 & 18 & & & & & & & & \\
\hline \multirow[t]{4}{*}{ All (39) } & 0.01 & -0.32 & & & - & 2 & 3 & & & & & & & & \\
\hline & $(0.16)$ & $-(0.31)$ & & -0.008 & + & 0 & 1 & & & & & & & & \\
\hline & 0.01 & -0.39 & 0.27 & & - & 0 & 60 & & & & & & & & \\
\hline & $(0.21)$ & $-(0.39)$ & (1.13) & 0.062 & + & 0 & 213 & & & & & & & & \\
\hline
\end{tabular}


returns variation as the measurement interval increases. However, the effect is small. What is most noticeable in the tables is that the industry effect coefficient and explanatory power increases substantially as the measurement interval increases for the traded goods industries. For the whole world, the average adjusted $R^{2}$ for regressions that have only the exchange rate increases from 0.004 to 0.015 as one goes from weekly data to annual data and the average slope goes from 0.01 to -0.05 . For traded goods industries, the adjusted $R^{2}$ changes from 0.003 to 0.016 and the average exchange rate slope coefficient goes from -0.04 to -0.13 . However, the adjusted average $R^{2}$ for the traded goods industries for the regressions that have both exchange rate shocks and industry shocks increases from two percent to ten percent and the average slope on the industry shocks goes from 0.08 to 0.32 . Importantly, controlling for industry effects does affect the exchange rate slope coefficient when one uses yearly returns. The slope for the exchange rate in traded goods industries is -0.13 when the regression does not include industry effects and is -0.21 when such effects are included. For the U.S., the slope for the exchange rate is 0.03 when one does not control for industry effects and is -0.07 when one does. Both exchange rate shocks and industry shocks have the most explanatory power for the traded goods industry in the UK. The U.S. is the country where exchange rate shocks and industry shocks explain the least variation across measurement intervals. Using yearly data, the average adjusted $R^{2}$ for all U.S. industries in regressions that include industry effects is 0.7 . The main conclusion one can draw from examining the yearly return regressions is that cross-country industry effects increase for traded goods industries, particularly in the UK, Canada, and Japan. At the yearly interval, the regression with only the exchange rate has an average adjusted $R^{2}$ of $1.5 \%$. The inclusion of the foreign industry index boosts the average adjusted $R^{2}$ to $5.3 \%$, indicating that industry effects are more important than currency effects in explaining variation in returns, particularly over long time horizons. 


\section{Conclusion.}

At the industry level, the impact of exchange rate shocks is trivial for U.S. industries and small even in the countries where exchange rate shocks matter the most, like Japan. Shocks to foreign industries have a positive impact on U.S. industries, so that common industry factors are more important than competitive effects. The importance of common industry shocks grows as the measurement interval is lengthened. However, together, industry and exchange rate shocks explain little for all measurement intervals. Our evidence shows that industry effects are relatively unimportant but that there is no evidence that an industry in a country benefits at the expense of the same industry in another country. In other words, what's good for GM is good for Toyota on average.

Given our results, why are exchange rate shocks and industry shocks not more important? Note first that our results do not say that exchange rate shocks are unimportant for all firms. However, these effects are unimportant in value-weighted portfolios. Large firms may simply be importers as well as exporters and may have exposures to different currencies of different signs. In other words, the exchange rate shocks wash out in the aggregate. Further, firms may hedge or may adapt rapidly to exchange rate shocks so that they have little effects on firm value. ${ }^{7}$ Alternatively, it could be that the financial markets fail to evaluate exposures properly. However, it is difficult to believe that they could do so consistently across countries and over a twenty-two year period. Further, our evidence would then suggest that they have not gotten any better over time, which is hard to believe also.

\footnotetext{
${ }^{7}$ See Géczy, Minton and Schrand (1997) for evidence on the use of derivatives by firms to hedge currency exposures.
} 


\section{Data Appendix}

\section{A. Returns}

Returns are calculated as the difference between the log of the Datastream return index. The industry index returns are value-weighted return indices adjusted for dividends and stock splits. The weekly return indices for most countries begin on January 1, 1975 and thus the first return is on January 8,1975 . Thus, the weekly return series corresponds to the return from previous Monday's close to the current Monday's close. Monthly returns are calculated from closing return index prices at the first of the month.

\section{B. Exchange Rates}

The change in the exchange rate is calculated as the logged difference between the current exchange rate and the previous month's dollar/currency exchange rate. The direct US dollar per currency exchange rate is taken from the Barclays international bank. For earlier years of the sample and for the dollar/pound exchange rate, the direct currency per dollar quote is not available but the series is constructed from UK cross-rates quoted by National Westminster Bank. Simple correlations between the UK/dollar cross-rate exchange changes and those obtained from the respective market quotes reveal that all corresponding series have correlations greater than 0.95 for the periods for which both currency rates are available. 


\section{References}

Adler, M. and B. Dumas, 1983, "International portfolio selection and corporation finance: A synthesis," Journal of Finance 38, 925-984.

Allayannis, G., 1996a, "Time variation of exchange rate exposure: An industry analysis," New York University working paper.

Allayannis, G., 1996b, “Time variation of exchange rate exposure: An industry analysis," New York University working paper.

Bartov E., and G. Bodnar, 1994, "Firm valuation, earnings expectations and the exchange-rate effect, Journal of Finance 49, 1755-1785.

Bodnar, G., and Gentry, W., 1993, Exchange rate exposure and industry characteristics: Evidence from Canada, Japan, and the U.S., Journal of International Money and Finance 12, 2945.

DeSantis, G. and B. Gerard, 1997, "Time-Varying Risk and International Portfolio Diversification with Contagion Bear Markets," Journal of Finance, forthcoming.

Géczy, C., B. Minton, and C. Schrand, 1997, "Why firms use currency derivatives," Journal of Finance 52, 1323-1355.

Griffin, J. G. and G. A. Karolyi, 1997, "Another Look at the Role of the Industrial Structure of Markets for International Diversification Strategies," Arizona State and Western Ontario Working Paper.

Hamao Y., R. Masulis and V. Ng, 1990, "Correlations in Price Changes and Volatility across International Stock Markets," Review of Financial Studies 3, 281-307.

He, J. and L. Ng, 1997, "Foreign Exchange Exposure, Risk, and the Japanese Stock Market" Journal of Finance, forthcoming.

Heston, S. L. and K. G. Rouwenhorst, 1994, "Does industrial structure explain the benefits of international diversification," Journal of Financial Economics 36, 3-27.

Jorion, P., 1990, "The exchange rate exposure of U.S. multinationals, Journal of Business 63, 331-345.

Karolyi, G. A., and R. M. Stulz, 1996, "Why do markets move together? An Investigation of U.S.-Japan Stock Return Comovements" Journal of Finance, 51, 951-986.

Longin, F. and B. Solnik, 1995, "Is the Correlation in International Equity Returns Constant: 1960-1990?" Journal of International Money and Finance 14, 3-26. 
Roll, R., 1992, "Industrial structure and the comparative behavior of international stock market indices," Journal of Finance 47, 3-42.

Williamson, R., 1997, "Exchange Rate Exposure, Competitiveness, and Firm Valuation: Evidence from the World Automotive Industry," Ohio State University Working Paper. 